NELSON LACAVA FILHO

Legitimidade do Direito Penal Militar no Estado Democrático de Direito:

Hierarquia e disciplina como bases sistêmicas

\author{
Tese de Doutorado
}

Orientador: Professor Titular Renato de Mello Jorge Silveira

UNIVERSIDADE DE SÃO PAULO

FACULDADE DE DIREITO

São Paulo - SP

2018 
NELSON LACAVA FILHO

\section{Legitimidade do Direito Penal Militar no Estado Democrático de Direito:}

Hierarquia e disciplina como bases sistêmicas

Tese de Doutorado apresentada à Banca Examinadora do Programa de Pós-Graduação em Direito, da Faculdade de Direito da Universidade de São Paulo, como exigência parcial para obtenção do título de Doutor em Direito na área de concentração Direito Penal, Medicina Forense e Criminologia, sob a orientação do Professor Titular Renato de Mello Jorge Silveira.

UNIVERSIDADE DE SÃO PAULO

FACULDADE DE DIREITO

São Paulo - SP 


\section{Lacava Filho, Nelson}

Legitimidade do Direito Penal Militar no Estado Democrático de Direito: Hierarquia e disciplina como bases sistêmicas/Nelson Lacava Filho: orientador Renato de Mello Jorge Silveira -- São Paulo, 2018.

$333 \mathrm{p}$.

Tese (Doutorado - Programa de Pós-Graduação em Direito Penal, Medicina Forense e Criminologia) - Faculdade de Direito, Universidade de São Paulo, 2018.

1. Direito Penal Militar. 2. Estado Democrático de Direito. 3. Legitimidade. 4. Bases Sistêmicas. I. Silveira, Renato de Mello Jorge, orientador. II. Título. 
"Haveis de ouvir falar sobre guerras e rumores de guerras.

Cuidado para não vos alarmardes. É preciso que essas coisas aconteçam, mas ainda não é o fim"

(Mt. 24:6). 
Para Thaís, minha mulher, meu amor;

Elizabeth, minha mãe, que me ensinou o valor da disciplina;

Isabella, Cecília, Heloísa, minhas filhas, e Carolina, minha sobrinha, alegria de viver;

Lígia, minha irmã, que tem no seu coração os mesmos brios que os meus;

Sueli, minha sogra, sempre certa nas adversidades.

Mulheres da minha família, guerreiras, das quais sou arrimo. 


\section{AGRADECIMENTOS}

A Deus, que me deu saúde e meios para realizar esse trabalho.

Ao meu orientador, Professor Renato de Mello Jorge Silveira, pela paciência, trabalho, serenidade e amizade de tantos anos, e por sua contribuição, não apenas nesse trabalho, mas na minha formação e construção de carreira.

Aos Professores Alamiro Velludo Salvador Neto e Luciano Anderson de Sousa, sem contar a irmandade e carinho durante esses anos todos, pelas contribuições e incentivos quando do exame de qualificação.

Ao Professor Antonio Luis Chaves Camargo (in memorian), pelas inspirações ora aqui, ora ali, durante a redação e estruturação do trabalho.

À Professora Ana Elisa Liberatore Silva Bechara, pela sugestão de bibliografia que fez toda a diferença.

Aos meus colegas de Ministério Público Militar, a saber, o Procurador-Geral Jaime de Cássio Miranda, o Conselheiro Marcelo Weitzel Rabello de Souza, o Subprocurador-geral de Justiça Militar Alexandre Concesi, o Procurador de Justiça Militar Alexandre José de Barros Leal Saraiva, e os Promotores de Justiça Militar Alexandre Reis de Carvalho e Marcos José Pinto pelos apoios fundamentais sem os quais não teria sido possível concluir a tese.

Ao Professor José Carlos Couto de Carvalho, pela ajuda com bibliografia e trocas de experiências.

Ao Comandante do Exército, General Villas Boas e seu Estado Maior, General Thomaz, ao Almirante Barros Coutinho e ao Coronel Aviador Daniel Cavalcante de Mendonça por me franquearem as portas das Forças Armadas.

Aos Ministros do Superior Tribunal Militar, Flavio Flores da Cunha Bierrenbach, Marcos Augusto Leal de Azevedo e Marcos Martins Torres (in memoriam), pela visão que me deram da Justiça Militar.

A todos, os meus agradecimentos. 


\section{RESUMO}

LACAVA FILHO, Nelson. Legitimidade do Direito Penal Militar no Estado Democrático de Direito: Hierarquia e disciplina como bases sistêmicas. 2018. 333 p. Tese de Doutorado Faculdade de Direito, Universidade de São Paulo, São Paulo, 2018.

A presente tese tem como objetivo defender a legitimidade do sistema penal militar no contexto do Estado Democrático de Direito e estabelecer vetores para a reforma do referido sistema, atualmente em curso no Brasil. O trabalho se subdivide em quatro partes. Na primeira parte, após uma breve contextualização do problema a ser investigado, são lançadas as bases histórico-normativas do sistema penal militar brasileiro. Assim, é feito um apanhado da história do Direito Penal Militar desde a Antiguidade, Idade Média, momento codificador e a recepção do Direito Militar no Brasil e suas codificações. Na segunda parte, analisa-se, a partir da realidade social e dos atuais empregos das Forças Armadas, se o sistema penal castrense brasileiro, baseado na dicotomia "Tempo de Paz" e "Tempo de Guerra", seria consentâneo com as suas finalidades, tendo em vista, sobretudo, o fenômeno das "novas guerras" e o "combate assimétrico". Na terceira parte, busca-se estabelecer as bases para uma legitimação dogmática do sistema penal militar tendo em vista os princípios e garantias do Estado Democrático de Direito e os traços diferenciadores do conceito de crime militar, com especial ênfase aos critérios ratione personae, ratione materiae, ratione loci, ratione temporis e ratione legis. Além disso, com base nas investigações da dogmática penal alemã, no que tange ao "sistema integral de Direito Penal", demonstra-se o ganho em qualidade que representa o julgamento realizado pelo escabinato em detrimento do juiz singular nas causas militares. Na quarta e última parte, são propostos os vetores a serem seguidos em uma reforma do sistema. Principia-se por um apanhado das reformas realizadas em diversos países pelo mundo, tanto no que diz respeito ao Direito Penal Militar quanto no que concerne ao Direito Processual Penal Militar, com ênfase na jurisdição castrense. Faz-se uma breve análise de como esta reforma está em curso no Brasil e da nova alteração no conceito de crime militar em tempo de paz, estabelecida pela Lei 13.491/2017. Defende-se que o Direito Penal Militar, por seus fundamentos sistêmicos diversos do Direito Penal comum, justifica a existência de uma codificação com Parte Geral diversa do Código Penal comum, e, na reforma, deve buscar, ao invés de se harmonizar aos princípios do sistema penal comum, aproximar-se do Direito Internacional Penal, especialmente no que diz respeito às normas do Tribunal Penal Internacional relativas aos crimes de guerra e genocídio. Nesse contexto, noções como a "responsabilidade do comandante" e os princípios da "necessidade" e "proporcionalidade militares", extraídos do Direito Internacional dos Conflitos Armados, são importantes traços legitimadores do julgamento pelo escabinato. Além disso, analisa-se que a tendência de expandir a competência da Justiça Militar da União para o julgamento de causas envolvendo matéria disciplinar militar, já operada no âmbito da jurisdição militar estadual e defendida, inclusive em relatório do $\mathrm{CNJ}$, para a justiça militar da União, além de representar, certo ponto, um retorno às origens da Justiça Militar da União, é uma constatação inconsciente de que não há diferenciação entre o conceito material de crime militar e infração disciplinar militar, o que justifica um sistema de Direito Penal Militar integral. Pontua-se, ainda, que, diante da utilização cada vez mais corriqueira das Forças Armadas em atividades de "policiamento", não se justificam as pressões pela desmilitarização das Polícias Militares e, também, pela extinção das Justiças Militares dos Estados.

PALAVRAS-CHAVES: Direito Penal Militar. Estado Democrático de Direito. Legitimidade. Bases Sistêmicas. 


\begin{abstract}
LACAVA FILHO, Nelson. Legitimacy of Military Criminal Law: hierarchy and discipline as systemic bases. 2018. 333 p. Doctor - Faculty of Law, University of São Paulo, São Paulo, 2018.

The aim of the present thesis is to defend the legitimacy of the military penal system in the context of a Democratic State under the rule of law and establish guidelines for the reform of this system, which is currently in force in Brazil. The work is divided into four parts. In the first part, following a brief contextualization of the problem, the historical and normative bases of the military penal system in Brazil are outlined. Thus, a survey is conducted of Military Criminal Law since ancient times and the Middle Ages to the time of drafting and adopting Military Criminal Law in Brazil. In the second part, from the social reality and current deployment of the Armed Forces, an analysis is conducted of whether the military penal system, based on the dichotomy of "Peacetime" and "Wartime", is actually in keeping with its purposes. This analysis is conducted especially with a view to the phenomenon of "new wars" and "asymmetric warfare". The third part seeks to establish the bases for the dogmatic legitimacy of the military penal system, bearing in mind the principles and guarantees for a Democratic State under the rule of law and the differentiating traits of the concept of military crime, with special emphasis on the criteria of ratione personae, ratione materiae, ratione loci, ratione temporis and ratione legis. Furthermore, based on investigations of the German penal dogma with regard to the "integral system of Penal Law", the gain in quality represented by a trial by jury rather than a judge when dealing with military cases. In the fourth and final part, the guidelines to be followed in a reformed system are proposed. It begins with a survey of the reforms made in a number of countries around the world concerning Military Criminal Law and Military Criminal Procedural Law, with emphasis on military jurisdiction. A brief analysis is conducted of how this reform is ongoing in Brazil and the new alteration in the concept of military crime in peacetime, as established by Law 13.491/2017. An argument is made in favor of Military Criminal Law through its diverse systemic fundamentals of the common Penal Code. This justifies the existence of a code as a General Part different from the common Penal Code. In the reform, instead of the principles of the common penal code being harmonized, it would draw nearer to those of International Criminal Law, especially regarding the norms of the International Criminal Court concerning war crimes and genocide. In this context, notions such as the "responsibility of the commander" and the principles of "need" and "military proportionality", extracted from the International Law of Armed Conflict, are important legitimizing traits of trial by jury in a court of law. Furthermore, there is a tendency to extend the competence of Federal Military Justice to include the trial of cases involving military discipline, which already operate in the context of state military jurisdiction and defended, even by the NJC report, to federal military justice. This, in addition to representing a return to the origins of federal military justice, is an unconscious statement that there is no differentiation between the concept of military crime and military disciplinary misdemeanors, which justifies a system of a full Military Penal Code. It should also be pointed out that with the increasing everyday use of the Armed Forces in "policing" activities, the pressures arguing for the demilitarization of the Military Police cannot be justified, nor can the pressures to abolish state Military Courts.
\end{abstract}

KEYWORDS: Military Criminal Law. Democracy. Legitimacy.Systemic Bases. 


\section{RIASSUNTO}

LACAVA FILHO, Nelson. Legittimitá del Diritto Penale Militare nel Stato Democratico di Diritto: gerarchia i disciplina militari come basi sistemiche. 2018. 333 p. Doctor - Faculty of Law, University of São Paulo, São Paulo, 2018.

Lo scopo di questa tesi è difendere la legittimità del sistema penale militare nel contesto dello Stato Democratico di Diritto e stabilire vettori per la riforma di tale sistema, attualmente in corso in Brasile. La tesi è suddivisa in quattro parti. Nella prima parte, dopo una breve contestualizzazione del problema ad essere indagato, vengono lanciate le basi storiconormative del sistema penale militare brasiliano. Così, viene fatto un sondaggio della storia del Diritto Penale Militare fin dall'antichità, Medioevo, momento di codifica e la ricezione del Diritto Militare in Brasile e le sue codifiche. Nella seconda parte, dalla realtà sociale ed dai lavori attuali delle Forze Armate, viene analizzato se il sistema di giustizia penale militare brasiliano, basato sulla dicotomia "Tempo di Pace" e "Tempo di Guerra", sarebbe coerente con i suoi scopi, soprattutto in considerazione del fenomeno delle "nuove guerre" e del "combattimento asimmetrico". La terza parte mira a stabilire le basi per una legittimazione dogmatica del sistema penale militare in considerazione dei principi e delle garanzie dello Stato Democratico di Diritto e delle caratteristiche distintive del concetto di crimine militare, con particolare attenzione ai criteri ratione personae, ratione materiae, ratione loci, ratione temporis e ratione legis. Inoltre, basato sulle indagini della dogmatica criminale tedesca riguardanti il "sistema integrale di Diritto Penale", sono dimostrati i guadagni di qualità rappresentati dal giudizio compiuto dallo scabinato a scapito del giudice singolare nelle cause militari. Nella quarta e ultima parte, vengono proposti i vettori da seguire in una riforma del sistema. Iniziamo da una panoramica delle riforme realizzate in diversi paesi in tutto il mondo, sia per quanto riguarda il Diritto Penale Militare come per quanto riguarda il Diritto Processuale Penale Militare, con enfasi sulla giurisdizione militare. Si fa una breve analisi di come questa riforma è in corso in Brasile e il nuovo cambiamento del concetto di crimine militare in tempo di pace, istituito dalla Legge 13.491/2017. Si sostiene che il Diritto Penale Militare, grazie ai suoi fondamenti sistemici diversi dal Diritto Penale comune, giustifica l'esistenza di una codifica con Parte Generale diversa dal Codice Penale comune e, nella riforma, esso dovrebbe cercare di ravvicinarsi al Diritto Internazionale Penale piuttosto che armonizzarsi ai principi del sistema penale comune, in particolare per quanto riguarda le norme del Tribunale Penale Internazionale relative ai crimini di guerra e al genocidio. In questo contesto, nozioni come la "responsabilità del comandante" ed i principi della "necessità" e della "proporzionalità militare", estratte dal Diritto Internazionale dei Conflitti Armati, sono importanti tratti legittimanti del giudizio dallo scabinato. Inoltre, si analizza che la tendenza ad estendere la competenza della Giustizia Militare dell'Unione per il giudizio delle cause che riguardano questioni disciplinari militari, già operata nell'ambito della giurisdizione militare dello Stato e difesa anche nel rapporto del CNJ, per la giustizia militare dell'Unione, oltre a rappresentare, ad un certo punto, un ritorno alle origini della Giustizia Militare dell'Unione, è una scoperta inconscia che non vi è alcuna differenziazione tra il concetto materiale di crimine militare e d'infrazione disciplinare militare, che giustifica un sistema di Diritto Penale Militare integrale. Si nota inoltre che, dato l'uso sempre più comune delle Forze Armate nelle attività di "polizia", le pressioni per la smilitarizzazione della Polizia Militare ed anche l'estinzione della Giustizia Militare degli Stati, non sono giustificate.

PAROLE CHIAVE: Diritto Penale Militare. Stato Democratico Di Diritto. Legittimità. Basi Sistemiche. 


\section{SUMÁRIO}

INTRODUÇÃO

CAPÍTULO INTRODUTÓRIO - PARADOXOS DE UM SUBSISTEMA POUCO CONHECIDO

PRIMEIRA PARTE - BASES HISTÓRICAS E NORMATIVAS DO DIREITO PENAL

MILITAR

1.1 BREVE HISTÓRICO DO DIREITO PENAL MILITAR …........................................ 24

1.1.1. Histórico do Direito Penal Militar no Brasil ....................................................................... 38

1.1.1.1. Os Artigos de Guerra de Conde Lippe e o Direito Militar no Brasil Colônia e

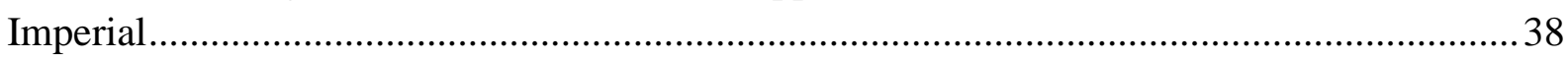

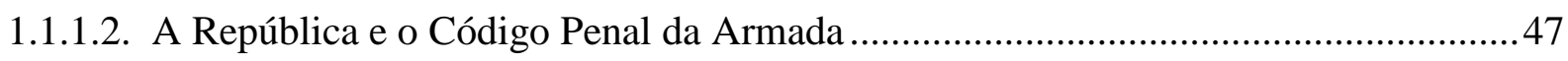

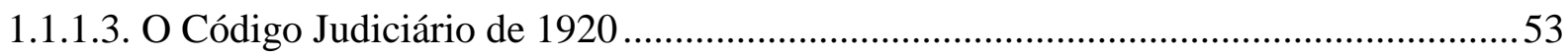

1.1.1.4. O Direito Penal Militar no período da Segunda Guerra Mundial ..............................60

1.1.1.5. O Direito Penal Militar nos anos do Regime Militar (os anos de 1964 a 1985) .........63

1.1.2. SISTEMA DE DIREITO PENAL BRASILEIRO PÓS CONSTITUIÇÃO DE 1988 ...69

SEGUNDA PARTE - DA LEGITIMIDADE NORMATIVO EXISTENCIAL DO

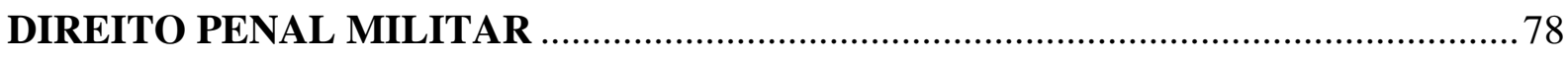

2.1 LEGITIMIDADE DO DIREITO PENAL MILITAR: LEGITIMAÇÃO EXISTENCIAL

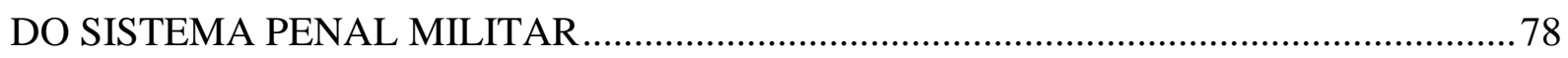

2.1.1. Legitimação do ponto de vista posto - guerra e dissuasão ……..................................... 86

2.1.2. Legitimação do ponto de vista contemporâneo - Operações de Paz, GLO, Policiamento

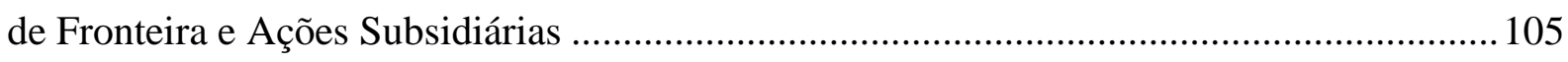

TERCEIRA PARTE - BASES PARA UMA LEGITIMAÇÃO DOGMÁTICA DO

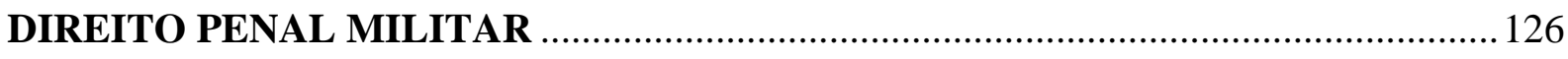

3.1. ESTADO DEMOCRÁTICO DE DIREITO E PRINCÍPIOS PENAIS ..........................126

3.1.1. Bem Jurídico Penal e conceito de Crime Militar......................................................... 134

3.1.1.1. Hierarquia e disciplina e os princípios e valores da vida militar............................. 158

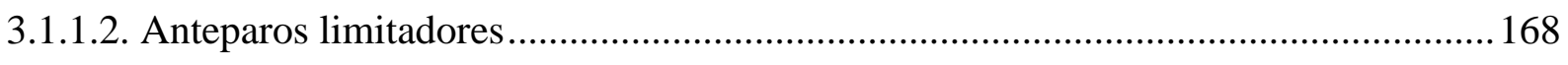

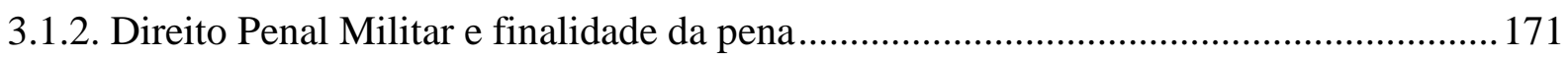

3.1.3. Sistema Integral de Direito Penal e Direito Penal Militar......................................... 181

QUARTA PARTE - A REFORMA DO DIREITO PENAL MILITAR ........................ 196

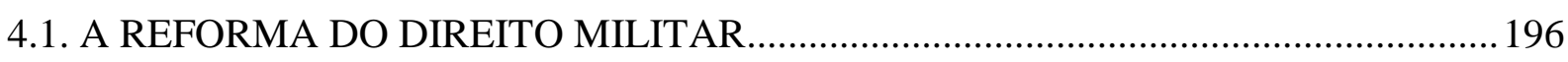

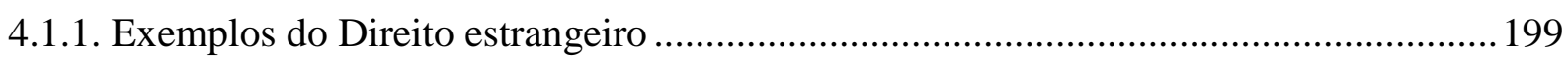

4.1.2. A jurisdição penal militar no direito comparado ........................................................206 
4.1.3. A realidade brasileira

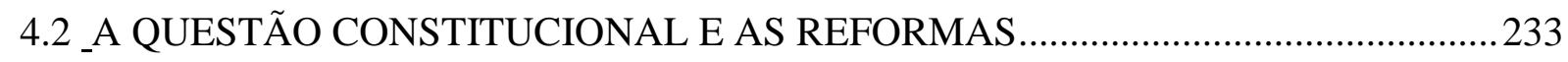

4.2.1. O Sistema Penal Militar, o Tribunal Penal Internacional e as Operações de Paz ........248

4.2.1.1 Do Direito Internacional da Guerra, breve síntese de suas bases históricas e sua necessária relação com o direito repressivo castrense .......................................................2248

4.2.1.2. Princípios de Direito Internacional Humanitário e Jurisdição Militar ......................259

4.2.1.3. Problemas de Direito Penal, Penal Internacional no contexto do emprego de forças militares em suas novas missões no cenário das relações internacionais pós-guerra fria .......273

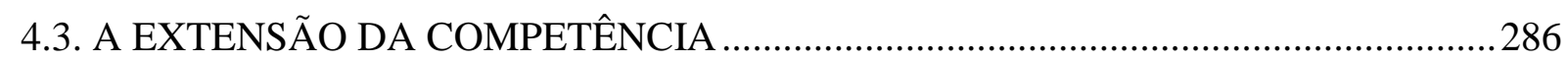

4.3.1. Direito Disciplinar Militar e Direito Penal Militar - Distinção Sistêmica ...................288

4.4 DIREITO PENAL MILITAR, SEGURANÇA PÚBLICA INTERNA E POLÍCIAS MILITARES - UM TEMA BASTANTE CONTROVERTIDO ..........................................297

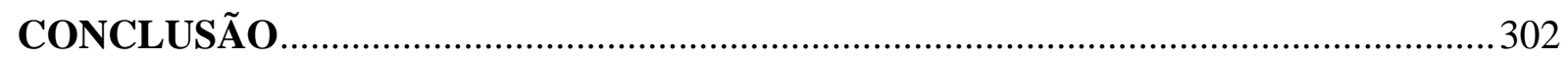

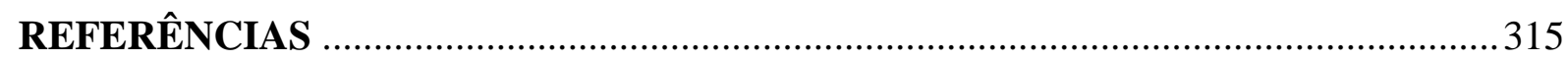





\section{INTRODUÇÃO}

O presente trabalho tem como escopo analisar a legitimidade de um sistema de Direito Penal Militar autônomo com foco no sistema penal militar federal, tendo como paradigma o Estado Democrático de Direito, e a relação dos vetores hierarquia e disciplina, princípios basilares de organização das Forças Armadas, como princípios reitores na fundamentação de um sistema repressivo castrense com traços diversos do sistema de Direito Penal comum.

Para tanto, três indagações nortearam a presente investigação: a primeira é se seria legítima a autonomia do sistema de Direito Penal Militar no Estado Democrático de Direito; a segunda, partindo do pressuposto de que deveria ser considerada legítima a autonomia do referido sistema, se este se encontra compatível com o Estado Democrático de Direito e o contexto social atual e, por fim, se o referido sistema penal militar não se encontra compatível, quais paradigmas devem nortear possíveis alterações legislativas.

Como respostas a estas indagações defende-se a tese de que a autonomia do Direito Penal Militar e seu subsistema repressivo são legítimos tendo em vista que, muito embora haja similitude com o sistema de Direito Penal comum, há uma gama de peculiaridades que possibilitam uma sistematização diversa. Essas peculiaridades inviabilizam, ou pelo menos, tornam contraproducente a existência de uma Parte Geral comum, como tem sido a tendência de alguns ordenamentos modernos.

Por outro lado, muito embora a autonomia do Direito Penal Militar seja legítima, defende-se que o ordenamento repressivo militar, tal como posto no Brasil, encontra déficit de legitimidade que, não obstante não o coloque em contraposição com o Estado Democrático de Direito e o contexto social (contexto de emprego das Forças Armadas e outras corporações militares), traz dificuldades não só na aplicação de suas normas pelos tribunais, mas, também, na própria operacionalidade das missões militares.

Propõe-se que, na busca da diminuição desse "déficit de legitimidade", muito embora a solução intuitiva seja harmonizar o Direito Penal Militar ao Direito Penal comum (coisa que vem ocorrendo no Brasil desde o início do século XX), os paradigmas a serem levados em consideração a fim de nortearem possíveis reformas do sistema repressivo militar devem ser as atuais formas de emprego das forças e corporações militares, com especial preocupação quanto a uma codificação dos "crimes de guerra". Nesse diapasão, tendo em vista que a necessidade, proporcionalidade e estratégias do "ataque", de acordo com o Direito Internacional dos Conflitos Armados, constituem elementos importantes para se aferir a responsabilidade dos militares envolvidos, o escabinato é, por excelência, a estrutura 
judicante mais apropriada a conduzir o julgamento dos crimes militares, consolidando-se o sistema repressivo militar como um subsistema integral de Direito Penal autônomo.

É a tese que se pretende provar.

Tomando por base a presente tese, após um breve capítulo introdutório em que será aprofundada a problematização da pesquisa, a presente investigação se conduzirá em quatro partes.

$\mathrm{Na}$ primeira parte, composta por um único capítulo, serão apresentadas as bases históricas e normativas do ordenamento repressivo castrense brasileiro. O aprofundamento da pesquisa no que diz respeito ao referido tema justifica-se em razão da gênese diversa das primeiras normas de Direito Militar, nelas incluindo-se o Direito Penal e Processual Penal Militar desde a Antiguidade e o seu aprimoramento e desenvolvimento quando da formação do conceito de Estado Moderno.

$\mathrm{Na}$ segunda parte, composta também por um único grande capítulo, buscar-se-á, partindo-se do pressuposto de que a legitimidade de um ordenamento jurídico não apenas se pauta pelos princípios éticos e valores que o fundamentam, mas deve estar aberta e servir à realidade filosófica e social do momento histórico em que é aplicado, tratar-se-á da legitimação normativa existencial do Direito Penal Militar, abordando, em que pese de forma perfunctória, a realidade de emprego das Forças Armadas no Brasil, tanto no seu aspecto tradicional de defesa externa da Pátria - emprego em situação de guerra declarada e preparo com vistas à dissuasão - quanto no que diz respeito ao seu emprego contemporâneo em Operações de Paz, Operações de Garantia da Lei e da Ordem, Policiamento e Fronteira e Ações Subsidiárias, tendo como pano de fundo o conceito das "novas guerras" e do "combate assimétrico".

Na terceira parte, voltando para o sistema penal militar propriamente dito, em um único capítulo, serão explicitadas as bases para uma legitimação dogmática do Direito Penal Militar, tendo como cerne os princípios e direitos e garantias fundamentais que estruturam o Estado Democrático de Direito, discorrendo-se, sobretudo, a respeito dos tormentosos temas dos conceitos de crime militar e bem jurídico militar e de como a metodologia criada a partir das investigações a respeito do denominado sistema integral de direito penal servem de bases não só para fundamentar a legitimidade da autonomia do Direito Penal Militar, mas também de todo um sistema repressivo castrense que não envolve apenas uma legislação penal material diversa, mas também uma legislação processual diferenciada bem como a própria manutenção do escabinato. 
Na quarta parte, tendo como que por defendida a manutenção da autonomia do sistema penal militar brasileiro, em um grande capítulo, subdividido em quatro grandes tópicos com seus subitens, serão apresentados paradigmas e sugestões para uma reforma do direito repressivo castrense brasileiro. Assim, no primeiro capítulo dessa parte, far-se-á um apanhado de como alguns outros países vêm "remodelando" o seu direito repressivo militar e dos principais projetos de lei e decisões dos Tribunais Superiores quanto ao tema no Brasil. No segundo capítulo dessa parte, será analisada relação entre a reforma do referido sistema e a Constituição brasileira bem como com o Direito Internacional dos Direito Humanos e o Direito Internacional dos Conflitos Armados. E, no último capítulo dessa derradeira parte, muito embora o enfoque principal seja o sistema repressivo castrense com foco no que diz respeito à sua aplicação no contexto das Forças Armadas, será tratada, mesmo que de forma superficial, a intrincada questão referente as Polícias Militares e a Justiça Militar Estadual.

Por fim, esperando haver convencido o leitor da tese que se pretende provar com a presente investigação e, diletantismo a parte, suscitar indagações que estimulem novas pesquisas sobre temário tão complexo e intrigante, concluir-se-á por pontos. 


\section{CONCLUSÃO}

1. O Direito militar, muito embora fundamente todo um ramo do Poder Judiciário brasileiro, é uma matéria, na maioria das vezes, esquecida e desconhecida pela grande maioria dos doutrinadores e pelo próprio legislador brasileiro encontra-se em reformas, sendo crucial que se analise se sua autonomia, enquanto sistema, legitima-se e quais os vetores que deveriam norteá-la, ponderando como esses vetores delineariam a estrutura do crime militar.

2. O Direito Penal Militar e os sistemas de jurisdição militares possuem bases históricas bastante remotas, havendo, já na Antiguidade, sobretudo entre os gregos, hebreus e, principalmente, romanos, normas referentes às condutas dos militares em suas atividades.

a. A primeira legislação penal militar aplicada no Brasil elevado a Reino Unido a Portugal e Algarves foram justamente os "artigos de guerra" do Conde Lippe que, nada mais eram que a "parte penal" das ordenanças promulgadas pelo Marquês de Pombal a fim de organizar a Armada Portuguesa para a Guerra contra a Espanha.

Da mesma forma que muitos países da Europa, o Brasil teve, no âmbito do Direito Penal Militar, uma codificação bastante tardia, tendo sido aplicados por todo o Império os artigos de guerra do Conde Lippe.

b. Com o advento da Proclamação da República, o Brasil foi brindado com sua primeira codificação militar, o Código Penal da Armada que, posteriormente, veio a ser estendido também ao Exército Brasileiro.

c. No ano de 1920, após muitas críticas ao Código Penal da Armada e ao Sistema de Justiça Militar por juristas como Hélio Lobo, Esmeraldino Bandeira e Rui Barbosa, entra em vigor, no Governo de Epitácio Pessoa, o Código de Justiça Militar, bastante criticado por setores das Forças Armadas pelos seus traços notadamente civilistas. Além de alterações nas composições do Superior Tribunal Militar e dos Conselhos de Justiça, observou-se a criação do Ministério Público Militar e da Advocacia de Ofício, embrião da Defensoria Pública da União.

A Reforma "civilista" teria seu apogeu quando, na Constituição de 1934, a Justiça Militar da União veio a fazer parte, integralmente, do Poder Judiciário Brasileiro, o que a faz diferente da grande maioria das jurisdições militares do resto do mundo que ainda se mantém atreladas ao Poder Executivo.

Nesse período, de um embate jurisprudencial entre o Superior Tribunal Militar, que procurava estender o conceito de crime militar, e o Supremo Tribunal Federal, que procurava restringir o referido conceito, foi que, do manejo dos critérios ratione personae, 
ratione materiae, ratione loci e ratione temporis, construiu-se o conceito ex vi legis de crime militar que acabou sendo adotado na Constituição de 1937 e está consagrado na tradição constitucional brasileira até atualidade.

d. Durante a Segunda Guerra Mundial, o Direito Militar brasileiro sofreu diversas alterações legislativas, sobretudo no que diz respeito ao processo e normas de organização judiciária militar. Foi editado, também, um novo Código Penal Militar que se notabilizou pela introdução da medida de segurança como sanção na sua Parte Geral e algumas modificações no que diz respeito aos crimes militares contra o patrimônio, crimes de perigo comum e contra a administração pública, estendendo-se a jurisdição militar, definitivamente, aos civis.

Nesse período, também, por força da Constituição de 1944, a Justiça Militar Estadual, que já existia desde o século XIX em alguns Estados, passou a integrar os Poderes Judiciários dos Estado, sendo o Brasil o único país no mundo que possui duas jurisdições militares.

e. Durante o Regime Militar, no ano de 1969, entraram em vigor os atuais Códigos Penal e Processual Penal Militares.

O Código Penal Militar notabiliza-se pelo fato de possuir, além de uma Parte Geral, repleta de princípios diferenciadores do Direito Penal comum, uma Parte Especial subdividida em 2 (dois) livros, um destinado aos crimes militares em tempos de paz e outro aos crimes militares em tempos de guerra.

O referido Código, em termos de fundamentação filosófica e estrutura sistêmica da teoria do crime e das penas, era um espelho do "famigerado" Projeto Hungria, que nunca foi aplicado no Brasil, mas que mantinha os pressupostos de uma matriz causalnaturalista. No que tange ao Processo Penal militar, o novo Código que acompanhava o Código Penal Militar trazia bastantes avanços ao Processo Penal Militar, sendo considerado, por muito tempo, superior ao Código de Processo Penal comum.

Mas o grande traço diferenciador do período não é o Direito Militar, por excelência, mas a utilização da jurisdição militar a fim de se processar e julgar os crimes da Lei de Segurança Nacional. Muito se tem argumentado no sentido de que a utilização de tribunais pelas ditaduras para a persecução de referidos crimes, como ocorreu em diversos países pelo mundo, é um privilégio dos militares para que fiquem impunes dos seus crimes cometidos em defesa do Estado, e uma injustiça para com os acusados que passam a ser perseguidos pela jurisdição militar que servirá de braço jurídico legitimador do regime de 
força. Ocorre que, no Brasil, conforme depoimento dos próprios advogados e juristas que militaram na Justiça Militar da União, o julgamento dos processos, mesmo nos momentos mais "fechados" do Regime em que se chegou até a suprimir o habeas corpus, deu-se de forma independente e muitas vezes, até garantista.

f. Com o advento da Constituição de 1988, o julgamento dos crimes contra a segurança nacional passou a ser da competência da Justiça Federal comum. Manteve-se, entretanto, a Justiça Militar da União, para julgar os crimes militares definidos em lei, e as Justiças Militares Estaduais, para o julgamento dos policiais militares e bombeiros, nos crimes militares.

Observa-se um total descompasso no que tange à produção legislativa quanto à matéria militar, haja vista que, não obstante o sistema penal comum e o sistema penal militar sejam sistemas diversos, as alterações, num e noutro sistema, podem ter o condão de interferir em ambos de forma não esperada e desestruturante. Exemplos dessas "reformas" foram a da Lei 9.099/95 (Lei dos Juizados Especiais); a Lei 8.072/90 (Lei dos Crimes Hediondos); a Lei 11.343/2006 (Lei Anti-Drogas) e a Lei 9299/96 (Lei Hélio Bicudo, que transfere a competência do processamento e julgamento dos crimes militares contra civis para a Vara do Júri).

Até outubro de 2017, as Forças Armadas brasileiras encontravam-se inseguras com relação às suas atuações em decorrência das modalidades de emprego previstas na Lei Complementar 97/99, que regulamenta o disposto no art. 142 da Constituição Federal, estabelecendo parâmetros para seu preparo e emprego com vistas não apenas ao binômio "guerra/dissuasão" (tempo de guerra X tempo de paz), mas também a outras modalidades de emprego como as Operações de Garantia da Lei e da Ordem, o Policiamento de Fronteiras, as ações subsidiárias, auxílio na defesa civil e as missões de paz. A Lei 13.491/2017 vem como tentativa de corrigir esse descompasso.

3. É tarefa precípua da ciência do Direito colocar o direito posto em contato com o espírito do seu tempo e reconhecer ou desconhecer sua legitimidade a partir desse espírito. Foge-se, portanto, à ideia positivista jurídica no sentido de se analisar o Direito tão somente sob o prisma formal, buscando analisá-lo sob sua vertente material.

Assim, a presente tese teve como pressuposto analisar a legitimidade do Sistema Penal Castrense não apenas sob o aspecto normativo constitucional e com relação ao Direito Internacional Público, mas, também, tendo em vista a realidade social na qual o referido sistema está inserido. 
a. Muito embora a Nova Ordem Mundial se paute pelo princípio da não agressão e haja uma grande preocupação dos Estados no sentido de não se declarar formalmente a guerra, o Estado brasileiro, dadas as suas riquezas naturais e culturais e sua posição de destaque no cenário das relações internacionais entre os povos, não descarta por completo a possibilidade de ser vítima de uma injusta agressão internacional que lhe possa envolver em uma "guerra total". Sendo assim, não seria o caso de se afastar por completo o binômio "tempo de guerra" e "tempo de paz", sob o qual se baseia o Sistema de Direito Penal Militar Nacional, mesmo porque, no tempo de paz, enquanto se preparam para a guerra, as Forças Armadas exercem dissuasão a eventuais interesses adversos de outros países que coloquem em risco a soberania do Estado Democrático de Direito.

b. Entretanto, no cenário das Relações Internacionais entre os Estados e dos Conflitos pós-Guerra-do-Golfo, exsurgem modalidades de emprego das Forças Militares no mundo todo e no Brasil em circunstâncias que passam a ser denominadas "novas guerras" em que se destaca o "combate assimétrico". Esses novos empregos, que vão desde a guerra de guerrilha entre Estados e entre Estado e seus insurgentes, até serviços de policiamento com vistas ao restabalecimento da segurança interna dos Estados, no que tange ao terrorismo e ao narcotráfico, determinaram que o Direito Internacional dos Conflitos Armados abandonasse o conceito de "guerra" a fim de estender a proteção humanitária aos seres humanos quando, e em razão, dos combates.

No Brasil, tais situações são regulados pela Lei Complementar 97/99 e são, na prática, efetiva "zona cinzenta" entre situações de Policiamento ostensivo, naturalmente realizado pelas Políciais Militares dos Estados que se utilizavam do uso proporcional e progressivo da força, e realidades de combate efetivo, ou seja, de "conflito armado", em que se pode até justificar-se o uso letal da força, diante do indiscutível poder bélico daqueles que se contrapõem às forças do Estado Brasileiro, tanto em território nacional, como observado em diversas Operações de Garantia da Lei e da Ordem, no Rio de Janeiro, Espírito Santo, etc., quanto no Exterior, quando no cumprimento de mandato da ONU em Operações de Paz cada vez mais "robustas". Para estas situações, no âmbito do Direito Penal Militar interno permanecia verdadeiro vácuo legislativo, até então apenas preenchido com alterações no Código Penal Militar que submetia o processamento e julgamento à Justiça Militar da União, da morte decorrente do "tiro de abate" quando em Operação da Força Aérea em repressão ao tráfico internacional de drogas.

4. A análise do modelo de Estado em que se insere determinado direito posto é extremamente importante no que concerne à sua legitimidade, haja vista que é por meio dela 
que se pauta a coerência do ordenamento com o modelo político social em que se insere. $\mathrm{O}$ modelo Estado Democrático de Direito estabeleceu uma série de princípios que devem nortear o seu sistema penal, como o princípio da legalidade, a função preventiva e o princípio da dignidade humana, dos quais decorrem uma série de outros subprincípios. No âmbito do Direito Penal Militar, a aplicação dos referidos princípios é mais complexa, haja vista que deve ser aliada a outros fundamentos, notadamente, a defesa da soberania da pátria, missão das Forças Armadas, que pautadas nos vetores valorativos da hierarquia e disciplina, é função do referido ramo do direito reforçar.

a. Ao tutelar as Forças Armadas e as polícias militares como instituições, o Direito Penal Militar, assim como o Direito Penal comum serve para que o cidadão militar e o próprio civil não sejam afetados em sua diginidade humana de forma arbitrária pelo Estado, tem a função de tutelar bens jurídicos especiais cuja lesão implicaria na própria ineficiência das referidas instituições no mister de assegurar a paz social, tanto no âmbito externo quanto no interno, bem como tutelar os próprios direitos fundamentais nas situações em conflito.

b. Dadas as missões que a Constituição atribui às forças armadas e às Polícias Militares, segue uma relação especial de sujeição que justifica a limitação em direitos fundamentais que tem no Direito Penal e Disciplinas instrumentos de reforço. O Direito Militar serve de elemento garantidor do próprio sistema e, por essa razão, tem peculiaridades que justificam sua autonomia, não só no âmbito legislativo, mas também no que diz respeito ao trato pelo judiciário.

O crime militar é o ilícito penal que lesa ou põe em perigo o bem jurídico institucional da defesa da pátria e outros bens jurídicos penais estebelecidos por vetores normativos oriundos dos dispositivos que tratam das Forças Armadas, Policiais e Bombeiros Militares e suas missões, na Constituição.

Hierarquia e disciplina não seriam, assim, os únicos bens jurídicos diferenciadores e legitimadores do sistema de Direito Penal Militar, nem os mais importantes, pois seriam apenas bens jurídicos instrumentais a tutelar algo bem mais importante que seria, no âmbito das Forças Armadas, reforçar a eficiência destas instituições no mister de garantir a segurança externa e interna do Estado Democrático de Direito e, no âmbito das Polícias Militares e Corpos de Bombeiros Militares, garantir a ordem pública e, assim, em ambos os casos, a normalidade da vida em sociedade no Estado Democrático de Direito.

O crime militar é um injusto especial de elevado potencial de danosidade social, pois coloca em risco a própria estrutura do Estado Democrático de Direito, não sendo 
salutar fazer uma análise de seu conceito "em tempo de paz" sem referência ao "tempo de guerra".

Os crimes militares, como delitos especiais e, portanto, delitos de infração de dever, são, na sua maioria, crimes pluriofensivos, ofendendo mais de um bem jurídico, que pode ser inerente a uma função estatal de defesa ou segurança e até mesmo individual.

c. Além da hierarquia e disciplina, podem ser considerados como bens jurídicos penais a serem tutelados pelo sistema repressivo castrense, bens inerentes às missões das instituições militares, como a neutralidade política, o dever militar, o serviço militar, a coesão da tropa, etc.

Tal expectro valorativo é extremamente difícil de restringir, haja vista se basear na "vida da caserna", atividade peculiar desses especialíssimos servidores do Estado, que servem à sociedade nessas instituições primárias que assumem características de instituições fechadas.

d. Restringir o conceito de crime militar tão somente aos vetores do art. 142 e 143 da Constituição da República é incoerente com o critério ex vi legis estabelecido pelo Poder Constituinte originário para o conceito de crime militar e contraditório ao viés de manutenção da segurança externa a interna de emprego das Forças Armadas, sejam quais forem as atividades que estejam exercendo.

É um contrassenso o Estado, por sua inegável incapacidade, impor, por meio de lei, missões às Forças Armadas, muitas vezes afetas à segurança pública, sem lhes dar os instrumentos, sem lhes dar os instrumentos jurídicos adequados para tal.

e. Outro traço diferenciador do sistema penal militar a legitimar sua autonomia se dá quanto à finalidade da pena. Em tempos de guerra, a dogmática Espanhola é enfática no sentido de que tem função preventivo geral negativa, ao contrário do que vem pregando a dogmática majoritária, no âmbito do Direito Penal comum, que se porta no sentido de que sua função seria preventivo geral positiva.

No que diz respeito à função da pena no Direito Penal Militar em tempo de paz, há divergências doutrinárias que vão desde a ideia de que não se deveria fazer diferenciação entre os sistemas quanto a este aspecto, até considerações no sentido de que a função da pena seria "reafirmar o Direito Penal Militar e os valores a ele inerentes".

Alia-se, aqui, ao entendimento no sentido de que, também em tempo de paz, a função da pena seria preventivo geral negativa, exercendo forte influência dissuasória aos seus destinatários. 
Mas o grande diferencial quanto às penas no âmbito do sistema penal castrense é quanto ao regime penintenciário, devendo haver uma especial atenção ao fato de que o militar condenado à pena privativa de liberdade superior a 2 (dois) anos, por crime militar ou comum, fica sujeito a ser excluído da sua respectiva Força ou Corporação, podendo alimentar o já caótico sistema prisional comum brasileiro, sem que haja qualquer tipo de reinserção à sociedade e, muito menos, diferente do que ocorre em outros países como a Itália e Espanha, recuperação a fim de seu restabelecimento para a carreira das armas.

Além disso, o fato de se submeterem os militares ao mesmo sistema penitenciário que os sentenciados comuns, gera problemas de duas ordens: ou os coloca em risco no que diz respeito à sua vida, incolumidade física e outros direitos fundamentais, haja vista ser isso potencializado pela atividade que exercem; ou corre-se o risco de serem cooptados pelo crime organizado, para quem seus conhecimentos e aptidões seriam extremamente úteis.

5. A fim de estabelecer o conceito material de crime em um sistema aberto, a dogmática penal alemã de orientação funcionalista vem desenvolvendo investigação no sentido de se analisar o sistema penal de forma integral, tendo como paradigmas critérios como necessidade e merecimento de pena, que serão avaliados não apenas no âmbito legislativo, mas também do judiciário, já que o Direito Penal deve ser aplicado tendo em vista seus fins, não de forma isolada, mas na sua inter-relação com o Direito Constitucional e o Direito Processual Penal.

Tais considerações justificam a jurisdição militar especializada tal como posta no Brasil, como escabinato, tendo em vista que no processo de formação do direito, um órgão colegiado misto, composto por um juiz conhecedor do Direito e outros juízes leigos, enriquecerá o "diálogo da culpabilidade", introduzindo às discussões dos casos concretos os valores, os conhecimentos, os direitos e os deveres da realidade da caserna, fazendo efetiva a construção teórica do "tunel da realidade", criada por Gustav Radbruch e revisitada, sob a perspectiva argumentativa, por Arthur Kaufmann.

6. A primeira dificuldade no sentido de se estabelecer uma reforma no sistema penal militar vem do fato de sua jurisdição militar ser ligada à ideia de ter sido instrumento dos regimes autoritários do Século XX, havendo fortes correntes no sentido de sua extinção nos países em que ainda ela existe.

A tutela realizada pelo sistema repressivo castrense, portanto, se dá em dupla via: de um lado visa a proteger a soberania (ou, no caso dos Policiais Militares, a eficiência na 
manutenção da Segurança Pública) e, por outro, proteger as populações civis, os Direitos Humanos, dos arbítrios do Estado e dos excessos da guerra.

Essa realidade na qual se busca a tutela do sistema penal castrense é ampliada pelo fato de que, mesmo naqueles estados que não estejam envolvidos em guerras de defesa, dissoluções intestinas, na luta contra o terrorismo e criminalidade organizada, etc., há sempre a possibilidade de suas Forças Armadas serem utilizadas em Operações de Paz ou, como no casos de diversos países europeus, em operações conjuntas como as da OTAN em que há preocupação quanto ao respeito às normas de Direito Internacional Público, mais notadamente de Direito Internacional dos Direitos Humanos e de Direito Internacional dos Conflitos Armados, cuja infração pode consubstanciar em infração ao Direito Penal Internacional, especialmente às normas do Tribunal Penal Internacional.

a. Três são os modelos de sistemas penais militares pelo mundo: o tradicional, também denominado, de codificação integral, por possuir num mesmo texto legislativo normas de Direito Penal, Direito Processual Penal e Disciplinar Militar; o modelo autônomo, em que há codificações separadas tratando de Direito Penal Militar e Processo Penal Militar e o sistema de incriminação conjunta, que insere as normas de direito penal militar nos textos legislativos comuns.

Analisando as posturas dos diversos países pelo mundo no que concerne ao trato do Direito Penal Militar, percebe-se que, durante o século XX, muitos dos países que sempre adotavam os modelos tradicional e autônomo quanto ao ordenamento repressivo castrense passaram, por razões históricas e políticas, a adotar o sistema de incriminação conjunta como, por exemplo, a França e a Alemanha.

Entre os países que ainda adotam sistemas penais militares especializados, merecem destaque a Itália, a Espanha e a Holanda que, adotando o modelo de codificação autônoma tal qual o Brasil, respectivamente, adotaram, o Código Penal Militar de Guerra quando dos Conflitos no Iraque e no Afeganistão (Itália); passou-se a utilizar o termo "conflito armado" em substituição ao termo "guerra", em código recém aprovado no ano de 2015 (Espanha); e insere e tipifica no Código Penal Militar os crimes de guerra, contra a humanidade e Genocídio (Holanda).

b. No que concerne à jurisdição militar há duas classificações que tentam explicar os sistemas pelo mundo.

A mais simplificada subdivide os sistemas em $i$ ) modelo saxão; ii) modelo europeu continental e iii) modelo de situações excepcionais. 
Na classificação complexa, os sistemas se subdividem em i) sistema anglosaxão; ii) sistema latino-romanista; iii) sistema dos países comunistas; iv) sistema de jurisdição excepcional e $v$ ) sistema dos países ibero-americanos.

No que diz respeito às reformas da jurisdição militar, são dignas de nota as alterações legislativas espanholas a fim de conferir e garantir legitimidade aos pronunciamentos dos juízes militares em sua prestação jurisdicional, como o fato de os oficiais generais escolhidos a fim de compor a sala $5^{\text {a }}$ do Supremo Tribunal Constitucional irem para a reserva tão logo assumam o cargo de Ministros daquela Suprema Corte e o dever de informar dos juízes militares de qualquer que seja a instância, caso percebam qualquer iniciativa do Executivo em influir em seus julgamentos.

Outra alteração relevante que vem sendo efetivada em diversos países tem relação com a independência do órgão de acusação, que tradicionalmente é exercido por um oficial membro do quadro das Forças Armadas e vem sendo transferida a civis, como já ocorre no Brasil, há um século, a fim de adequar o sistema ao princípio acusatório.

c. No Brasil, se há consenso no sentido de que deve haver uma reforma do sistema penal castrense, há dissenso no que diz respeito em que rumo esta deve se dar.

Durante um grande período de tempo a jurisprudência do Supremo Tribunal Federal tem exercido um importante papel de integração das normas do sistema penal militar à ordem constitucional de 1988, em que, no que tange ao Direito Penal Militar, ao mesmo tempo que impõe um conceito restritivo de crime militar, assevera a separação entre Direito Penal comum e especial. No que diz respeito ao Processo Penal Militar, tem-se admitido a aplicação de normas do processo penal comum ao referido sistema.

Outro vetor que tem sido levado em consideração é o do Direito Internacional dos Direitos Humanos que tem, nos tratados referentes à matéria assumidos pelo Brasil e nas decisões das Cortes Internacionais de Direitos Humanos, os principais elementos de discussão. Nesse contexto, destacam-se os 20 (vinte) princípios sobre administração da Justiça Militar estabelecidos pela Comissão de Direitos Humanos da ONU (Princípios “Decaux”). Sobre esses temas é importante ressaltar que a jurisprudência das Cortes Internacionais, especialmente no que diz respeito à submissão de civis à jurisdição militar, não deve ser aplicada ao caso brasileiro tendo em vista o pertencimento da jurisdição militar brasileira ao Poder Judiciário, a composição militar dos órgãos jurisdicionais militares (que possuem juízes civis nomeados após aprovação em concurso público e garantidos pela vitaliciedade, inamovibilidade e irredutibilidade de vencimentos), a submissão das decisões da Justiça 
Militar ao Supremo Tribunal Federal e o respeito ao princípio acusatório, haja vista ser o Ministério Público Militar da União ou dos Estados composto exclusivamente por civis.

A ideia de legitimação do Direito Penal Militar, no sentido de que este deve se aproximar, cada vez mais, do Direito Penal comum, muito embora seja intuitiva, não encontra respaldo nem na realidade, nem no tratamento dado ao tema pela Constituição.

Certo é que o Poder Constituinte Originário concebeu um necessário tratamento especial ao sistema repressivo castrense, haja vista que este serve como regime de reforço da especial relação de sujeição que determinados cidadãos têm em relação às missões constitucionais das instituições militares.

Além disso, há uma série de traços diferenciadores entre os sistemas que justificam a existência de uma Parte Geral do Direito Penal Militar, como o tratamento da aplicação da lei no espaço, a estreita relação entre o Direito Penal Militar e as normas de Direito Internacional Público; a preocupação em se delimitar as consequências jurídicas em conceitos no que diz respeito ao "tempo de guerra" e o "tempo de paz"; a integração da norma penal militar às normas administrativas militares como as 'regras de engajamento', 'tratados de aliança', 'acordos de força', 'ordens de operações', etc.; nas causas de exclusão do crime, como no caso do comandante de navio, aeronave ou praça de guerra que, na iminência de perigo ou grave calamidade, compele os subalternos por meios violentos, a executar serviços e manobras urgentes, para salvar a unidade ou vidas, ou evitar desânimo, o terror, a desordem, a rendição, a revolta ou o saque.

Outros princípios justificadores de uma Parte Geral do Direito Penal Militar são as diferenciações quanto a incidência da norma penal militar conforme as qualidades de superior e inferior dos agentes passivo e ativo do injusto especial militar; a impossibilidade de se alegar o desconhecimento da lei em matéria de serviço etc.

i. Outro traço característico que justifica a especialidade e autonomia do sistema penal militar em relação ao sistema comum que tem ligação com a Constituição é a sua relação mais intensa com o Direito Internacional Humanitário e o Direito Penal Internacional, haja vista ser o Direito Penal Militar que, a princípio, deve regular a matéria no plano interno, a fim de que o sistema penal internacional não venha a funcionar subsidiariamente, ingerindo no exercício da Jurisdição brasileira.

ii. Três premissas devem ser levadas em consideração no relacionamento entre Direito Militar, Direito Internacional dos Direitos Humanos e Direito Internacional Humanitário. A primeira é de que não obstante o respeito à dignidade da pessoa humana 
esteja no âmago dos dois ramos de Direito Internacional Público citados, o direito à vida não é um direito absoluto, sendo lícito, por vezes, ao Estado, matar.

A segunda premissa é que enquanto às Forças Armadas está autorizado o uso letal da força em suas atividades, às Polícias e Corpos de Bombeiros militares está somente autorizado o uso progressivo da força nas suas missões de garantia da Segurança Pública. A terceira premissa é que o Direito Humanitário se pauta por uma série de princípios, dos quais, destacam-se, no contexto dessa tese, o princípio da distinção e o princípio da proporcionalidade, como vetores.

O princípio da distinção terá crucial relevância no entrechoque com o Direito Penal Militar haja vista que parte da ideia de combatente e não combatente para conferir as prerrogativas do status de prisioneiro de guerra e não trabalha com a dicotomia militar/civil do Direito Penal Militar, pois o civil pode ser combatente. Por outro lado, o tratamento dado pelo Direito Penal Militar ao caso da espionagem é um indicativo da solução a ser dada aos chamados "combatentes irregulares" ou "combatentes ilegais", no contexto da guerra contra o terrorismo, no sentido de imprimir as garantias penais e processuais militares ao acusado, não obstante não tenha o status de combatente.

Pelos princípios da proporcionalidade e necessidade militares, é respeitado um mínimo ético nos combates que, por outro lado, afastaria a ocorrência dos crimes de guerra. Por tais princípios se avalia se a ação militar que causaria riscos para alvos civis, é efetivamente necessária para dar uma vantagem significativa ao esforço militar, no que tange à necessidade; e, no que tange à proporcionalidade, se os meios e métodos de combate não são excessivos em relação à vantagem militar concreta a ser alcançada. A análise de tais princípios induz ao pensamento lógico no sentido de que os órgãos jurisdicionais que tratarão sobre os casos concretos envolvendo a matéria devem ser compostos por indivíduos com profundo conhecimento da matéria militar, não só do Direito Militar, mas dos armamentos, meios, métodos de combate, dos níveis, operacional, tático, estratégico e, por vezes, até político.

iii. Outros aspectos do Direito Penal Internacional que merecem atenção ao Direito Penal Militar são a tipificação dos crimes de guerra e agressão; o instituto da "responsabilidade penal do comandante", previsto no art. 28 do Estatuto de Roma; a necessidade de homogeinização entre os sistemas de direito comparado com vistas a atender aos tratados de cooperação policial e jurisdicional no que tange a crimes internacionais, sobretudo o de genocídio etc. 
Há forte corrente no sentido de se estender a competência da Justiça Militar da União também para o julgamento das ações decorrentes das infrações disciplinares dos militares das Forças Armadas, assim como ocorre no âmbito da Justiça Militar Estadual, e causas civis relacionadas ao regime e carreira militares. Tal medida pode trazer convenientes e inconvenientes.

Como inconveniente, pode ser citado o fato de a Justiça Militar da União perder sua celeridade, qualidade fundamental quando se pensa na função de se resguardar os valores no seio da tropa. Como conveniente, pode ser citado o fato de que os juízes da Justiça Militar da União estariam mais afeitos à legislação e aos valores militares, havendo maior facilidade e justeza nos julgamentos dos feitos.

iv. De toda a forma, a ideia de transferir o processamento e julgamento das ações decorrentes dos atos disciplinares militares, em que pese não signifique que os atos de indisciplina serão “julgados” pela jurisdição militar, evoca duas constatações.

A primeira é que, de certa forma, dá-se um retorno às origens da jurisdição militar no Brasil, visto que essa tratava, também, da matéria administrativa militar.

A segunda constatação é que os contornos diferenciadores do conceito de crime militar e de infração penal militar são bastante tênues, sendo distinguidos em termos materiais apenas quanto à gravidade da lesão aos bens jurídicos militares, afrontados pelos respectivos atos e pela intensidade das sanções aplicadas tanto em um como em outro caso. As demais distinções seriam de natureza formal ou com relação à autoridade competente para declarar sua infração e impor sanções.

De forma inconsciente, haja vista os elementos de interligação entre o sistema penal militar e disciplinar militar e a inexistência de uma diferenciação material e efetiva do que seja infração penal militar e infração disciplinar militar, o movimento no sentido de se submeter à jurisdição especializada as ações cíveis quanto aos referidos atos disciplinares, principalmente, levando em consideração que não se está excluída por completo, a análise do seu mérito é um reconhecimento de que se busca a construção de algo assemelhado a um sistema penal militar integral.

7. A "desmilitarização" das polícias e a extinção das Justiças Militares Estaduais não se justificam no quadro da realidade social brasileira, haja vista que, o emprego das Forças Armadas em Operações de Garantia da Lei e da Ordem no Brasil se dá, justamente, em razão da impossibilidade dos órgãos de Segurança Pública, principalmente as polícias militares, de cumprirem seu mister constitucional. 
Às Policias Militares é reservado um papel de policiamento ostensivo, destinado a dissuadir o crime, e de contenção de distúrbios que será realizado da mesma forma pelo Estado, não havendo garantia de que será mais eficiente e mais humano, caso não seja realizado pela polícia desmilitarizada.

Pelo contrário, o fato de ser a polícia militarizada é indicativo de maior controle sobre ela, haja vista estarem submetidas a um controle mais rígido de seus deveres. Nessa esteira, suprimir-se a jurisdição militar seria diminuir a efetividade desse controle. 


\section{REFERÊNCIAS}

ABREU, Jorge Luiz Nogueira de. Direito administrativo militar. Rio de Janeiro: Forense, 2010.

AFONSO DA SILVA, José. Notícia sobre a jurisdição militar no Brasil. In: ROCHA, Maria Elizabeth Guimarães Teixeira; PETERSEN, Zilah Maria Callado Fadul. Bicentenário da Justiça Militar no Brasil: Coletânea de Estudos Jurídicos. Brasília: Superior Tribunal Militar, 2008 .

AlbUQUERQUE MELlO, Celso D. de. Direitos Humanos e Conflitos Armados. Rio de Janeiro: Renovar, 1997.

ALVES JUNIOR, Thomas. Curso de Direito Militar. Tomo II. Rio de Janeiro: Francisco Luiz Pinto e Comp. Editores, 1868.

ALVES-MARREIROS, Adriano; ROCHA, Guilherme; FREITAS, Ricardo. Direito Penal Militar: Teoria crítica \& prática. São Paulo, Método, 2015.

AMARAL JÚNIOR, Alberto do. O Direito de Assistência Humanitária. Rio de Janeiro: Renovar, 2003.

AMBOS, Kai. A Parte Geral do Direito Penal Internacional: bases para uma elaboração dogmática. Trad. Carlos Eduardo Adriano Japiassú e Daniel Andrés Raisman. São Paulo: Editora Revista dos Tribunais, 2008.

ANDRADE, Luís Filipe. O julgamento dos crimes militares em Portugal. Anais do $X$ seminário de Direito Militar, Brasília, STM, 2014.

ASSIS, Jorge Cesar de. Comentários ao Código Penal Militar. 8. ed. revista, atualizada e ampliada. Curitiba; Juruá Editora, 2014.

. Comentários ao Código Penal Militar. 8. ed. Curitiba: Juruá Editora, 2014.

Considerações sobre o policial militar da ativa e a prestação de serviços de segurança em horários de folga. In Direito Militar: aspectos penais, processuais penais e administrativos. 2. ed. revista e atualizada. Curitiba: Juruá Editora, 2008.

- Curso de Direito Disciplinar Militar: da simples transgressão ao processo Administrativo. 3. ed. Curitiba: Juruá Editora, 2012. 
ASSIS, Jorge Cesar de; COIMBRA NEVES, Cícero Robson; CUNHA, Fernando Luiz. Lições de Direito para a Atividade das Polícias Militares e das Forças Armadas. 6. ed. Curitiba: Juruá Editora, 2008.

AZEVEDO, Marcos Augusto Leal de. A Cadeia de Comando e como ela interage com a Justiça Militar do Brasil” in: ROCHA, Maria Elizabeth Guimarães Teixeira; PETERSEN, Zilah Maria Callado Fadul. Bicentenário da Justiça Militar no Brasil: Coletânea de Estudos Jurídicos. Brasília: Superior Tribunal Militar, 2008.

BACIGALUPO, Silvina. Autoria y participación en delitos de infracción de deber. Barcelona: Marcial Pons, 2007.

BANDEIRA, Esmeraldino O. T. Direito, Justiça e Processo Militar. 2. ed. Rio de Janeiro: Livraria Francisco Alves, 1919. $1^{\text {o }}$ vol.

Do Crime: suas espécies e configurações jurídicas. In Tratado de Direito

Penal Militar Brasileiro: Parte Geral. Rio de Janeiro: Jacintho Ribeiro dos Santos Editor, 1925.

Tratado de Direito Penal Militar Brasileiro: Parte Geral. Rio de Janeiro: Jacintho Ribeiro dos Santos Editor, 1925.

BECHARA, Ana Elisa Liberatore Silva. Bem Jurídico-Penal. São Paulo: Quartier Latin, 2014.

BECK, Ulrich. La sociedad del riesgo: hacia una nueva modernidad. Tradução Jorge Navarro, Daniel Jimenéz, Maria Rosa Borrás. Barcelona: Paidós, 2001.

BERCOVICI, Gilberto. Soberania e Constituição: para uma crítica do constitucionalismo. São Paulo: Quartier Latin do Brasil, 2008.

BERMÚDEZ F., Renato de. Historia del Derecho militar. Mexico: Grupo Criminogénesis, 2015.

BERNAL DE CASTILLO, Jesús. Derecho penal comparado: la definición del delito en los sistemas anglosajón y continental. Barcelona: Atelier, 2011.

BIA, Maria Teresa. European police and judicial cooperation in criminal matters and the crime of genocide. In: MAROTO, Manuel; SCHEUNEMANN, Daniel. El derecho penal entre la guerra y la paz. Cuenca: Ediciones de La Universidad de Castilla-La Mancha, 2009.

BIERRENBACH, Flavio Flores da Cunha. A Justiça Militar e o Estado de Direito. In RAMOS, Dircêo Torrecillas; ROTH, Ronaldo João; COSTA, Ilton Garcia da (Coord.). Direito Militar: doutrina e aplicações. Rio de Janeiro: Elsevier, 2011. 
. Dois séculos de justiça: presença das Arcadas no Tribunal mais antigo do Brasil. São Paulo: Lettera.doc, 2010.

BITENCOURT, Cezar Roberto. Tratado de Direito Penal: Parte geral 1. 15. ed. São Paulo: Saraiva, 2010.

BONELLI, Laurent. Obsesión securitária e ilegalismos populares en Francia, desde princípios de 1980. In BERGALLI, Roberto; RIVERA BEIRAS, Iñaki. Política Criminal de la Guerra. Barcelona: Anthropos, 2005.

BRASIL. Conselho Nacional de Justiça. Diagnóstico da Justiça Militar Federal e Estadual 2014 - Relatório Final Grupo de Trabalho - Portaria n. ${ }^{\circ}$ 216, de 29 de novembro de 2013. Brasília: CNJ, 2014.

. Ministério da Defesa. Livro Branco da Defesa Nacional. Brasília: Ministério da Defesa, 2012.

. Ministério da Defesa. Manual de Fundamentos. O Exército Brasileiro. Brasília: MD, 2014.

Marinha do Brasil. Tradições Navais. Disponível in <https://www.marinha.mil.br/content/tradicoes-navais $>$, acesso em 10/01/2018.

BRIGHAM, John. Anti-Antiterror: La codificación por colores y la Broma de la 'Seguridad Nacional'. In BERGALLI, Roberto; RIVERA BEIRAS, Iñaki. Política Criminal de la Guerra. Barcelona: Anthropos, 2005.

BRUNELlI, David; MAZZI, Giuseppe. Diritto Penale Militare. 4. ed. Milano: Giuffrè Editore, 2007.

CÁCERES, Waldo Martínez. A justiça Militar no Chile. Anais do X Seminário de Direito Militar, Brasília, Superior Tribunal Militar, 2014.

CANARIS, Claus-Wilhelm. Pensamento sistemático e conceito de sistema na ciência do direito. 3. ed. Lisboa: Fundação Calouste Gulbenkian, 2002.

CARNEIRO, Mario Tiburcio Gomes. Sabres e Togas: A surpreendente influência de uma tese jurídica. Prefácio. In LOBO, Helio. Sabres e Togas: a autonomia judicante militar. 2. ed. Rio de Janeiro: Borsói, 1960.

CÁRPENTER, Luiz Frederico Sáuerbronn. O direito penal militar brasileiro e o direito penal militar de outros povos cultos. Rio de Janeiro: J. Ribeiro dos Santos, 1914. 
CARVALHO, Esdras dos Santos. O direito processual penal militar numa visão garantista: a conformação do processo penal militar ao sistema constitucional acusatório como instrumento de efetivação dos direitos fundamentais na tutela penal militar. Rio de Janeiro: Lumen Juris, 2010.

CASSEB, Paulo Adib. A competência constitucional da Justiça Militar. In: RAMOS, Dircêo Torrecillas; ROTH, Ronaldo João; COSTA, Ilton Garcia da (Coord.). Direito Militar: doutrina e aplicações. Rio de Janeiro: Elsevier, 2011.

CHAVES CAMARGO, Antonio Luis. Culpabilidade e Reprovação Penal. São Paulo: Saraiva, 1994.

Sistema de penas, dogmática jurídico-penal e política criminal. São Paulo: Cultural Paulista, 2002.

CINELLI, Carlos Frederico. Direito Internacional Humanitário: ética e legitimidade na aplicação da força em conflitos armados. CURITIBA: Juruá, 2015.

CLAUSEWITZ, Carl von. Da Guerra. Tradução Maria Teresa Ramos. São Paulo: Martins Fontes, 2010.

CÓDIGO CRIMINAL DO IMPÉRIO apud PEIRANGELI, José Henrique. Códigos Penais do Brasil: Evolução histórica. 2. ed. São Paulo: Editora Revista dos Tribunais, 2001.

COIMBRA NEVES, Cicero Robson; STREIFINGER, Marcelo. Manual de Direito Penal Militar. 2. ed. São Paulo: Saraiva, 2012.

COLOM PIELLA, Guillem. Entre ares y atenea: el debate sobre la revolución en los assuntos militares. Madrid: Instituto Universitario “General Gutiérrez Mellado, 2008.

CÓRDOBA, Juan Antonio Navas. Las competencias civiles de la jurisdicción militar. Madrid: Ministério de Defesa, 1997.

CORRALES ELIZONDO, Agustín. Garantías materiales en el régimen disciplinário de la Guarda Civil. In: LEÓN VILLALBA, Francisco Javier de (coord). Derecho Penal y Disciplinario Militar. Valencia: Tirant lo Blanch, 2006.

COSTA, Helena Regina Lobo da. A dignidade humana: teorias de prevenção geral positiva. São Paulo: Editora Revista dos Tribunais, 2008.

COULANGES, Fustel de. A cidade antiga: estudo sobre o culto, o direito e as instituições da Grécia e de Roma. 2. ed. Tradução de José Cretella Junior e Agnes Cretella. São Paulo: Editora Revista dos Tribunais, 2011. 
CRUCIANI, Andrea. Applicable law in Peace support operations. In: MAROTO, Manuel; SCHEUNEMANN, Daniel. El derecho penal entre la guerra y la paz. Cuenca: Ediciones de La Universidad de Castilla-La Mancha, 2009.

CRUZ, Ione de Souza; AMIN MIGUEL, Claudio. Elementos de Direito Penal Militar - Parte Geral. 2. ed. Rio de Janeiro: Lumen Juris, 2009.

DA COSTA, Álvaro Mayrink. Crime Militar. 2. ed. Rio de Janeiro: Lumen Juris, 2005.

DAL LAGO, Alessandro. La Guerra-Mundo. In BERGALLI, Roberto; RIVERA BEIRAS, Iñaki. Política Criminal de la Guerra. Barcelona: Anthropos, 2005.

DALLARI, Dalmo de Abreu. O Poder dos Juízes. São Paulo: Saraiva, 1996.

DE SOUZA, Octavio Augusto Simon. Justiça Militar: uma comparação entre os sistemas constitucionais brasileiro e norteamericano. Curitiba: Juruá Editora, 2008.

DELMAS, Philippe. O belo futuro da guerra. Trad. Sérgio Guimarães. Rio de Janeiro: Record, 1996.

DELMAS-MARTY, Mirelle. Le Droit Pénal comme éthique de la mondialisation. In MAROTO, Manuel; SCHEUNEMANN, Daniel. El derecho penal entre la guerra y la paz. Cuenca: Ediciones de La Universidad de Castilla-La Mancha, 2009.

DEVEILLE-FONTINHA, Carla. A Cooperação Jurídica com a França em Crimes Militares. Anais do X Seminário de Direito Militar, STM, Brasília, 2014.

DI PIETRO, Maria Sylvia Zanella. Direito Administrativo. 15. ed. São Paulo: Atlas, 2003.

DOBEL, John Patrick. A teoria da corrupção. O Estado de S. Paulo, p. 117-118, 24/02/1980 e p. 119 e $141,02 / 03 / 1980$.

DOTTI, René Ariel. Curso de direito penal: parte geral. 4. ed. São Paulo: Revista dos Tribunais, 2012.

DUARTE, Antonio Pereira. A vedação da visita íntima no sistema prisional militar sob a a ótica da dignidade da pessoa humana. Revista do Ministério Público Militar, n. 26, ano 41, p. 87-88, nov. 2016.

; BORTOLLI, Clauro Roberto de Bortolli; FREITAS, Ricardo. O Ministério Público Militar e a as Forças Armadas na Segunda Guerra Mundial. In FREITAS, Ricardo et al. Memória histórica do Ministério Público Militar. Brasília: Ministério Público Militar, 2012. 
DUFOUR, André Joseph Philippe. O sistema de Justiça Militar Canadense. Anais do X Seminário de Direito Militar, Brasília, Superior Tribunal Militar, 2014.

ESER, Albin. Hacia un Derecho Penal Mundial. Trad. Enrique Díaz-Aranda, Héctor FixFierro, Manuel Cancio Meliá, Rocío Procel Sánchez, Said Escudero Irra, Teresa Manso Porto. Granada: Comares, 2009.

ESPINOSA, Alejandro Carlos. Justicia Militar em México. In: Diritto e processo. Antonio Palazzo (a cura di). Anuário giurídico. Universtá degli Studi di Perugia, anno 2011.

La condicion jurídica de los militares en México. Instituto de investigaciones juriicas

de la UNAM. Disponível em
<https://archivos.juridicas.unam.mx/www/bjv/libros/7/3005/7.pdf >. Acesso em 10 de janeiro de 2018.

ESPÍRITO SANTO, Vicente Antonio. Compêndio para a Cadeira da Escola Militar. Rio de Janeiro: Imprensa Nacional, 1902. V. II.

EXPOSIÇÃO de Motivos do Código Penal de 1969. Revista de informação legislativa, Brasília, Senado Federal, p. 155, out.dez.1969.

FERNÁNDEZ GARCIA, Isidro. Los derechos fundamentales de los militares. Madrid: Ministério de Defesa, 2015.

FERNANDEZ-TRESGUERRES, José Antonio. Reglas de enfrentamiento (ROE). In MAROTO, Manuel; SCHEUNEMANN, Daniel. El derecho penal entre la guerra y la paz. Cuenca: Ediciones de La Universidad de Castilla-La Mancha, 2009.

FIANDACA, Giovanni. Quale especialitá per il Diritto Penale Militare. Rivista Italiana de Dirito e Procedura Penale, ano LI, p. 1063, jul/set.2008.

FIGUEIREDO, Telma Angelica. Excludentes de Ilicitude no Direito Penal Militar. Rio de Janeiro: Lumen Juris, 2004.

FISS, Owen. Una Guerra Sin Igual: La Constitución en los tiempos del terrorismo. Trad. Francisca Giménez. Madrid: Marcial Pons, 2017.

FOURNIER, Sylvain. NATO military interventions abroad: how roe are adoptec and jurisdictional rights negotiated. In MAROTO, Manuel; SCHEUNEMANN, Daniel. Criminal Law betwenn war and Peace: justice and cooperation in criminal matters in internacional military interventions. Cuenca: Ediciones Catilla-La Mancha, 2009.

FREUND, Georg. Sobre la función legitimadora de la idea de fine en el sistema integral del derecho penal. In: WOLTER, Jürgen; FREUND, George. El sistema integral del derecho 
penal: Delito, determinación de la pena y proceso penal. Trad. Guillermo Benlloch Petit, Nuria Pastor Muñoz, Ramon Ragués I Vallés, Ricardo Robles Planas, Pablo Sánchez-Ostiz Gutiérrez, Jesús-María Silva Sánchez. Madrid: Marcial Pons, 2004.

FRISCH, Wolfgang. Delito y sistema del delito. In . El Sistema integral del Derecho Pena - Delito, determinación de la pena y processo penal. Madrid: Marcial Pons, 2004.

GALVÃO, Fernando. Direito Penal: teoria do crime. Belo Horizonte: D’Plácido, 2016.

GARCIA, Maria. Militares e cidadania: Dobel, a corrupção do Estado e as 'estruturas primárias' da sociedade. In RAMOS, Dircêo Torrecillas; ROTH, Ronaldo João; COSTA, Ilton Garcia da (Coord.). Direito Militar: doutrina e aplicações. Rio de Janeiro: Elsevier, 2011.

GERALDI, Orlando Eduardo. A justiça militar do Estado de São Paulo: os julgamentos em $2^{\mathrm{a}}$ instância e aspectos práticos. In: Justiça Militar: aspectos práticos, Curitiba: Juruá Editora, 2017.

GIDDENS, Anthony. Sociologia. Tradução de Alexandra Figueiredo, Catarina Lorga da Siva, Patricia Matos, Pedro Manuel Sena, Teresa Lima e Vasco Gil. 9. ed. Lisboa: Fundação Calouste Gulbenkian, 2013.

GIL GIL, Alícia. La violación como arma de guerra y su persecución como crimen internacional. In: ZAPATATERO, Luis Arroyo; NIETO MARTÍN, Adán. Piratas, mercenarios, soldados, jueces y policías: nuevos desafios del Derecho Penal Europeo e Internacional Cuenca: Ediciones de la Universidad de Castilla - La Mancha, 2010.

GIUDICELLI-DELAGE, Genevieve. Fonctions de police judiciaire des forces armées a l'étranger. In: MAROTO, Manuel; SCHEUNEMANN, Daniel. El derecho penal entre la guerra y la paz. Cuenca: Ediciones de La Universidad de Castilla-La Mancha, 2009.

GÓMEZ RIVERO, Carmen. La repressión penal de la pirateria marítica. Bases para a oportunidad de una reforma. In: ZAPATATERO, Luis Arroyo; NIETO MARTÍN, Adán. Piratas, mercenarios, soldados, jueces y policías: nuevos desafios del Derecho Penal Europeo e Internacional. Cuenca: Ediciones de la Universidad de Castilla -La Mancha, 2010.

GONZÁLES ROMÁN, Cristóbal. Ejército e integración ciudadana durante la República tardía. In PALAO VICENTE, Juan José (Ed.). Militares y civiles en la antigua Roma: dos mundos diferentes, dos mundos unidos. Salamanca: Ediciones Universidad de Salamanca, 2010.

GROTIUS, Hugo. O direito da Guerra e da Paz. 2. ed. Tradução de Ciro Mioranza. Local: UNIJUÍ, 2005. V. I. 
GUSMÃO, Chrysolito. A competência dos tribunais militares: Estudo jurídico e de legislação comparada. Rio de Janeiro: Typho Litho Pimenta de Mello \& Ruy Sachel, 1914.

. Direito Penal Militar: com anexos referentes à legislação penal militar brasileira. Rio de Janeiro: Jacinto Ribeiro dos Santos Editor, 1915.

GUTIÉRREZ, Juan Carlos; CANTÚ, Silvano. A restrição à jurisdição militar nos sistemas internacionais de proteção dos Direitos Humanos. SUR - revista internacional de direitos humanos, v. 7, n. 13, p. 75-97, dez. 2010.

HABERMAS, Jürgen. El Proyecto Kantiano y el Occidente Escindido. In: HABERMAS, Jurgen. El Occidente escindido. Traducción de José Luis Lópes de Lizaga. Madrid: Trotta, 2006.

La constitucionalización del Derecho Internacional. In El Ocidente Escindido. Trad. de José Luís López de Lizaga. Madrid: Trotta, 2006.

Que Significa el derribo del Monumento? In: El Ocidente Escindido. Trad. de José Luís López de Lizaga. Madrid: Trotta, 2006.

. Una entrevista sobre la Guerra Y La Paz. In El Ocidente Escindido. Trad. de José Luís López de Lizaga. Madrid: Trotta, 2006.

HARRINGTON, Christine. Antiterrorismo, anticonstitucionalismo: el creciente ascenso del autoritarismo en los Estados Unidos. In BERGALLI, Roberto; RIVERA BEIRAS, Iñaki. Política Criminal de la Guerra. Barcelona: Anthropos, 2005.

HASSEMER, Winfried. Prevención General y Aplicación de la pena. In: NAUCKE, Wolfgang; HASSEMER, Winfried; LÜDERSSEN, Klaus. Principales problemas de la prevención general. Trad. Gustavo Eduardo Aboso. Buenos Aires: Editorial B de F, 2004.

HESPANHA, Antonio Manuel. Introdução. In: GROTIUS, Hugo. O direito da Guerra e da Paz. 2. ed. Tradução de Ciro Mioranza. Local: UNIJUÍ, 2005. V. I.

HOBBES, Thomas. Leviatã ou a matéria, forma e poder de um estado eclesiástico e civil. Tradução Rosina D’Angina. 3. ed. São Paulo: Ícone, 2014.

HOBSBAWM, Eric J. A Era das Revoluções: 1789-1848. Trad. Maria Teresa Teixeira, Marcos Penchel. 33. ed. São Paulo, Paz \& Terra, 2014.

INTELISANO, Antonio. Italian judicial experiences on Peace Support Operations. In: MAROTO, Manuel; SCHEUNEMANN, Daniel. Criminal Law betwenn war and Peace: justice and cooperation in criminal matters in internacional military interventions. Cuenca: Ediciones Catilla-La Mancha, 2009. 
JAKOBS, Günther. Ciência do Direito: Técnica ou Humanística? Bogotá: Universidade Externato de Colombia, 1996.

Daño social? Anotaciones sobre un problema teórico fundamental en el Derecho Penal. In JAKOBS, Günther; POLAINO NAVARRETE, Miguel; POLAINO-ORTIS, Miguel. Bien Jurídico, Vigencia de la norma y Daño social. Lima: Ara Editores, 2010.

. Derecho Penal del enemigo. 2. ed. Navarra: Civitas, 2006.

Derecho penal parte general: fundamentos y teoria de la imputación. Trad. Joaquim Cuello Contreras, José Luis Serrano Gonzallez de Murillo. 2. ed. Madrid: Marcial Pons, 1997.

. El Derecho Penal como disciplina científica. Tradução castelhana de Alex Van Weelzel. Pamplona: Civitas, 2008.

JARA GÓMEZ, Ana M. La transformación de las operaciones de mantenimiento de la paz. Dimensiones e implicaciones de una construcción jurídica, política y militar compleja. In: OLARTE ENCABO, Sofía. Estudios Sobre Derecho Militar Y Defensa. Navarra: Thomson Reuters Aranzadi, 2015.

JESSBERGER, Florian. From 'Abu Ghraib' to the 'rumsfeld case'. In: MAROTO, Manuel; SCHEUNEMANN, Daniel. El derecho penal entre la guerra y la paz. Cuenca: Ediciones de La Universidad de Castilla-La Mancha, 2009.

JIMÉNEZ VILLAREJO, José. La organización de la jurisdicción penal militar y su evolución. In MAROTO, Manuel; SCHEUNEMANN, Daniel. El derecho penal entre la guerra y la paz. Cuenca: Ediciones de La Universidad de Castilla-La Mancha, 2009.

JUANES PECES, Ángel. Las causas de justificación en el Derecho Penal Militar. in: LEÓN VILLALBA, Francisco Javier (dir.). Derecho Penal Militar Cuestiones Fundamentales. Valencia: Tirant lo Blanch, 2014.

JULIO CESAR, Caio. A guerra civil. Tradução de Antonio da Silveira Mendonça. São Paulo: Estação Liberdade, 1999.

JUNGMANN, Raul. Medida corrige erro de origem que renovou regra de um século. Disponível em <http://www1.folha.uol.com.br/opiniao/2017/10/1931007-medida-corrigeerro-de-origem-que-revogou-regra-de-um-seculo.shtml>. Acesso em 10 de janeiro de 2018.

KALDOR, Mary. Reestructurar la seguridade global para el siglo XXI. In STIGLITZ, Joseph E. La búsqueda de la seguridade: pretección sin protecionismo y el desafio de la governanza mundial. Buenos Aires: Paidós, 2013. 
KAUFFMANN, Arthur. Filosofia do Direito. 5. ed. Prefácio e tradução Antônio Ulisses Cortês. Lisboa: Fundação Calouste Gulbenkian, 2014.

KESRSTING. Politik und Recht, 2000 apud PAWLIK, Michel. Ciudadanía y Derecho Penal: fundamentos de la teoria de la pena y del delito en un Estado de libertades. Barcelona: Atelier Libros Jurídicos, 2016.

KRIEGER, César Amorin. Direito Internacional Humanitário: o precedente do Comitê Internacional da Cruz Vermelha e o Tribunal Internacional. Curitiba: Juruá Editora, 2014.

KUHLEN, Lothar. ?Es posible limitar el derecho penal por médio de un concepto material de delito?" In: WOLTER, Jürgen; FREUND, George. (eds). El sistema integral del derecho penal: Delito, determinación de la pena y proceso penal. Trad. Guillermo Benlloch Petit, Nuria Pastor Muñoz, Ramon Ragués I Vallés, Ricardo Robles Planas, Pablo Sánchez-Ostiz Gutiérrez, Jesús-María Silva Sánchez. Madrid: Marcial Pons, 2004.

LA CUESTA, José Luis de. Prólogo a la edición española. in: ESER, Albin. Hacia un Derecho Penal Mundial. Trad. Enrique Díaz-Aranda, Héctor Fix-Fierro, Manuel Cancio Meliá, Rocío Procel Sánchez, Said Escudero Irra, Teresa Manso Porto. Granada: Comares, 2009.

LACAVA FILHO, Nelson. Da aferição da tipicidade objetiva dos crimes militares: uma defesa da continuidade do julgamento pelo escabinado nos crimes militares cometidos por civis em concurso com militares. Revista do Ministério Público Militar, Brasília/DF n. 24, ano XXXIX, p. 189-204, nov. 2014.

LASCANO, Carlos. Inter-american court of human rights and penal military justice. In: MAROTO, Manuel; SCHEUNEMANN, Daniel. Criminal Law betwenn war and Peace: justice and cooperation in criminal matters in internacional military interventions. Cuenca: Catilla-La Mancha, 2009.

LÉON VILlALBA, Francisco Javier de. Bases Del Derecho Penal Militar Español. Madrid: Iustel, 2016.

Prólogo. In (dir.). Derecho Penal Militar: cuestiones fundamentales. Valencia: Tirant to Blanch, 2014.

Convivencia del Derecho Penal y el Derecho sancionador militar. In: (coord). Derecho Penal y Disciplinario Militar. Valencia: Tirant lo Blanch, 2006.

LEÓN VILLALBA, Francisco Javier; JUANES PECES, Ángel; RODRÍGUEZVILLASANTE Y PRIETO, Jose Luis. El Código Penal Militar de 2015: reflexiones y comentarios. Valencia: Tirant lo blanch, 2017. 
LOBÃO, Celio. Direito Penal Militar. 3. ed. Brasília: Brasília Jurídica, 2006.

Direito Penal Militar. Direito Penal Especial. Direito Penal Comum. Direito Processual Especial. In: ASSOCIAÇÃO DOS MAGISTRADOS DAS JUSTIÇAS MILITARES ESTADUAIS. Direito Militar: história e doutrina - artigos inéditos. Florianópolis: AMJME, 2002.

LOBO, Helio. Sabres e Togas: a autonomia judicante militar. 2. ed. Rio de Janeiro: Borsói, 1960.

LOPES JR., Aury Lopes. Limite penal: Lei 13.491/2017 fez muito mais do que retirar os militares do tribunal do júri. Conjur, 20.10.2017.

LOPES, José Reinaldo de Lima. O Direito na História. 3. ed. São Paulo: Atlas, 2008.

LÓPEZ RAMÓN, Fernando. La caracterizacion jurídica de las Fuerzas Armadas. Madrid: Centro de Estudios Constitucionales, 1987.

LOPEZ SANCHEZ, José. Protección Penal de La Disciplina Militar. Madrid: Dykinson, S. L., 2007.

LOUREIRO NETO, José da Silva. Direito Penal Militar. 5. ed. São Paulo: Atlas, 2010.

MADRIGAL, Salvador Calderón. Las garantias materiales en el derecho sancionador militar. in: LEÓN VILLALBA, Francisco Javier de (coord). Derecho Penal y Disciplinario Militar. Valencia: Tirant lo Blanch, 2006.

MAGIOLI, Renaldo Quintas. Uma Justiça Especializada, muito especial. In: ROCHA, Maria Elizabeth Guimarães Teixeira; PETERSEN, Zilah Maria Callado Fadul. Bicentenário da Justiça Militar no Brasil. Brasília: Superior Tribunal Militar, 2008.

MANACORDA, Stefano. Entre la guerre et la paix: le droit penal en quêle de sa place. In: MAROTO, Manuel; SCHEUNEMANN, Daniel. El derecho penal entre la guerra y la paz. Cuenca: Ediciones de La Universidad de Castilla-La Mancha, 2009.

La abolición de la pena capital en Europa: el círculo virtuoso de la política criminal y los riesgos de ruptura. In: ARROYO ZAPATERO, Luis; NIETO MARTIN, Adán. Piratas, mercenarios, soldados, jueces y policías: nuevos desafios del derecho penal europeo e internacional. Cuenca: Ediciones de la Universidad de Castilla-La Mancha, 2010.

MANCHEGO, José F. Palomino. La unidad de jurisdicción en el Perú (a proposito de la justicia militar). In ROCHA, Maria Elizabeth Guimarães Teixeira; PETERSEN, Zilah Maria Callado Fadul. Bicentenário da Justiça Militar no Brasil - Coletânea de Estudos Jurídicos. Brasília: Superior Tribunal Militar, 2008. 
MARKY, Thomas. Curso elementar de Direito Romano. 8. ed. São Paulo: Saraiva, 1995.

MARTIN, Vitor Gómez. Los delitos especiales. Madrid: B de F, 2006.

MATAMOROS MARTÍNEZ, Rafael. Los límites de la Jurisdicción Militar. In: OLARTE ENCABO, Sofía (dir.); ORZA LINARES, Ramón María (coord.). Estudios sobre derecho militar y defesa. Navarra: Thomson Reuter Aranzadi, 2015.

McCANN, Frank. Soldados da pátria: história do Exército brasileiro (1889-1937). Trad. Laura Teixeira Motta. São Paulo: Companhia das Letras, 2007.

MEIRELLES, Hely Lopes. Direito Administrativo Brasileiro. 14. ed. São Paulo: Malheiros, 2008 .

MELlO, Celso D. de Albuquerque. Curso de Direito Internacional Público. $2^{\circ}$ vol. 12. ed. Rio de Janeiro: Renovar, 2000.

MENDOZA BUERGO, Blanca. El derecho penal en la sociedad del riesgo. Madrid: Civitas, 2001.

MEY, Edson. A Justiça Militar em outros países. Brasília: STM, 1999.

MILLÁN GARRIDO, Antonio. Prólogo a la primera edición. In Justicia Militar. 8. ed. Barcelona: Ariel, 2010.

MIR PUIG, Santiago. Derecho penal parte general. 8. ed. Buenos Aires: B de F LTDA, 2009. . Estado, pena y delito. Buenos Aires: B de F LTDA, 2013.

Introducción a las bases del derecho penal. 2. ed. Buenos Aires: B de F LTDA, 2009.

MIRANDA, Jorge. Manual de Direito Constitucional. Preliminares à experiência constitucional. 2. ed. Coimbra: Coimbra Editora, 1982.

MODROÑO, Luis Carlos Medina. Terror y criminologia en el Siglo XXI: Nevas Formas de Guerra. In: BERGALLI, Roberto; RIVERA BEIRAS, Iñaki. Política Criminal de la Guerra. Barcelona: Anthropos, 2005.

MOMMSEM, Teodoro. Derecho Penal romano. Bogotá: Temis, 1991.

MONET, Jean-Claud. Polícias e Sociedades na Europa. Trad. Mary Amazonas Leite de Barros. 2. ed. São Paulo: EdUSP, 2006. 
MONTESQUIEU. Do espírito das leis. Trad. Gabriela de Adrada Días Barbosa. Rio de Janeiro: Nova Fronteira, 2012.

MOREIRA ALVES, José Carlos. Direito Romano. 10. ed. Rio de Janeiro: Forense, 1997.

MOURA, Bruno de Oliveira. A não-punibilidade do excesso na legítima defesa. Coimbra: Coimbra Editora, 2013.

NAVAS CÓRDOBA, Juan Antonio. Las competencias civiles de la jurisdicción Militar. Madrid: Ministerio da Defensa, 1997.

NÓBREGA, Thalita Borin. A questão da Justiça Militar. Âmbito Jurídico, Rio Grande, XVI, n. 113, jun 2013. Disponível em: <http://www.ambitojuridico.com.br/site/index.php/?n_link=revista_artigos_leitura\&artigo_id=13304\&revista_cad erno=9>. Acesso em set 2014 .

ORTIZ, Mariana Tranchezi. Concurso de agentes nos delitos especiais. Dissertação de Mestrado. Universidade de São Paulo, USP, 2010.

OZAKI, Kuniko. Criminal law protection and accontability of participants in peacekkeping operations. In: MAROTO, Manuel; SCHEUNEMANN, Daniel. El derecho penal entre la guerra y la paz. Cuenca: Ediciones de La Universidad de Castilla-La Mancha, 2009.

PALMA, Najla Nassif. Tolerância zero contra abusos e exploração sexuais em missões de paz. Disponível em <https://medium.com/@esmpu/toler\%C3\%A2ncia-zero-contra-abusos-eexplora\%C3\%A7\%C3\%A3o-sexuais-em-miss\%C3\%B5es-de-paz-7c05cd26a8b6>. Acesso em 10 de janeiro de 2018.

PALMA, Rodrigo Freitas. Direito Militar Romano. Curitiba: Juruá Editora, 2010.

PAWLIK, Michael. Ciudadanía y Derecho Penal: fundamentos de la teoria de la pena y del delito en un Estado de libertades. Barcelona: Atelier Libros Jurídicos, 2016.

El funcionário policial como garante de impedir delitos. In La libertad institucionalizada. Estudios de Filosofia jurídica y derecho penal. Trad. Enrique Bacigalupo, Paola Dropulich, Pilar González Rivero, Marcelo Lerman, Jacobo López Barja de Quiroga, Teresa Manso Porto, Jorge Perdomo, Javier Sánchez-Vera Gómez-Trelles, Marcelo A. Sancinetti. Madrid: Marcial Pons, 2010.

El terrorista y su derecho sobre la posición teórico-jurídica del terrorismo moderno. In _. La libertad institucionalizada. Estudios de Filosofia jurídica y derecho penal. Trad. Enrique Bacigalupo, Paola Dropulich, Pilar González Rivero, Marcelo Lerman, Jacobo 
López Barja de Quiroga, Teresa Manso Porto, Jorge Perdomo, Javier Sánchez-Vera GómezTrelles, Marcelo A. Sancinetti. Madrid: Marcial Pons, 2010.

PEREIRA, Carlos Frederico de Oliveira. Direito Internacional Penal: a responsabilidade de comando no estatuto de Roma e sua implementação no código penal militar. Curitiba: Juruá Editora, 2010.

Gangues Territoriais e Direito Internacional dos Conflitos Armados. Curitiba: Juruá Editora, 2016.

PÉREZ LUÑO, Antonio Enrique. Derechos humanos Estado de Derecho y Constituicion. 8. ed. Madrid: Tecnos, 2003.

PETERSEN, Zilah Maria Callado Fadul. O civil na jurisdição penal militar brasileira. Anais do X Seminário de Direito Militar, Brasília, Superior Tribunal Militar, 2014.

PIERINI, Jean Paul. Rules of engagement, status of forces agréments and criminal law: diferente approaches as to the legal base of the conflictsof jurisdiction in respecto of foreign friendly fire. In: MAROTO, Manuel; SCHEUNEMANN, Daniel. El derecho penal entre la guerra y la paz. Cuenca: Ediciones de La Universidad de Castilla-La Mancha, 2009.

POMBO, Bárbara. Extinção de tribunais militares estaduais. Disponível em $<$ https://www.jota.info/justica/extincao-de-tribunais-militares-estaduais-09122014> Acesso em 10 de janeiro de 2018.

PORETSCHKIN, Alexander. A jurisdição militar na Alemanha. Anais do X seminário de Direito Militar, Brasília, STM, 2014.

PRADO, Luis Regis. Curso de direito penal brasileiro. Parte Geral. 9. ed. São Paulo: Editora Revista dos Tribunais, 2010. V. 1.

PRADO, Ney. As Forças Armadas nas Constituições de 1969 e 1988. In: RAMOS, Dircêo Torrecillas; ROTH, Ronaldo João; COSTA, Ilton Garcia da (Coord.). Direito Militar: doutrina e aplicações. Rio de Janeiro: Elsevier, 2011.

RABELLO DE SOUZA, Marcelo Weitzel. As novas missões das Forças Armadas e as lacunas no direito brasileiro. Revista do Ministério Público Militar, Brasília, n. 24, ano XXXIX, p. 17, nov. 2014.

RADBRUCH, Gustav. Rechtsphilosophie. GRGA, vol. 2, p. 58 e seg, 1993. In KAUFFMANN, Arthur. Filosofia do Direito. 5. ed. Prefácio e tradução Antônio Ulisses Cortês. Lisboa: Fundação Calouste Gulbenkian, 2014. 
RAMÍREZ, Juan Bustos. Introducción al derecho penal. 2. ed. Santa Fé de Bogotá: Editorial Temis S.A, 1994.

REICHARDT, H. Canabarro. Esbôço de uma História do Direito Militar Brasileiro. Jornal do Commercio, Rio de Janeiro, Rodrigues \& C, p. 11, 1947.

RI, Arno Dal; ZEN, Cássio Eduardo. Entre Versailles e Roma: a instituição de uma Jurisdição Penal Internacional Permanente como virada paradigmática na história do Direito Internacional. In: STEINER, Sylvia Helena; BRANT, Leonardo Nemer Caldeira. O Tribunal Penal Internacional: comentários ao Estatuto de Roma. Belo Horizonte: Del Rey, 2016.

RIVELO, Pier Paolo. Lezioni di diritto penale militare. 2. ed. Torino: G. Giappichelli Editore, 2012.

RIVERA BEIRAS, Iñaki. Introducción. In BEIRAS, Roberto; RIVERA BEIRAS, Iñaki (coords.). Política Criminal de la Guerra. Barcelona: Anthropos, 2005.

RODRIGUEZ-VILLASANTE Y PRIETO, José Luis. Asesinatos selectivos y ejecuciones extrajudiciales en los conflitos armados actuales. In: MAROTO, Manuel; SCHEUNEMANN, Daniel. El derecho penal entre la guerra y la paz. Cuenca: Ediciones de La Universidad de Castilla-La Mancha, 2009.

RODRIGUEZ-ZAPATA PÉREZ, Jorge. La jurisdicción militar en el art. 117.5 de la Constitución. In: GARCÍA LOZANO, Carlos (dir.). Jurisdicción Militar: aspectos penales y disciplinarios. Madrid: Consejo General del Poder Judicial, 2006.

ROGEIRO, Nuno. Guerra em Paz: a Defesa Nacional na Nova Desordem Mundial. Lisboa: Hugin, 2002.

ROMEIRO, Jorge Alberto. Curso de Direito Penal Militar: Parte Geral. São Paulo: Saraiva, 1994.

ROSA FILHO, Cherubim. A Justiça Militar da União através dos tempos. Brasília: STM, 2012.

ROSA, Paulo Tadeu Rodrigues. Código Penal Militar comentado artigo por artigo. 3. ed. Belo Horizonte: Líder, 2014.

Direito administrativo militar: teoria e prática. 3. ed. Rio de Janeiro: Lumen Juris, 2007.

ROSSETO, Enio Luiz. Código Penal Militar comentado. São Paulo: Editora Revista dos Tribunais, 2012. 
ROTH, Ronaldo João. O Princípio da Insignificância e o Direito Penal Militar: Drogas, Crimes Patrimoniais, e Disciplina e Hierarquia" in: RAMOS, Dircêo Torrecillas; ROTH, Ronaldo João; COSTA, Ilton Garcia da (Coord.). Direito Militar: doutrina e aplicações. Rio de Janeiro: Elsevier, 2011.

ROXIN, Claus. Derecho penal parte general: fundamentos. La estrutura de la teoria del delito. Trad. Diego-Manuel Luzón Peña, Miguel Díaz y Garcia Conlledo, Javier de Vicente Remesal. Madrid: Civitas, 1999. T. 1.

Política Criminal e Sistema Jurídico-Penal. Tradução Luís Greco Rio de Janeiro: Renovar, 2002.

Sentido e limites da pena estatal. In Problemas fundamentais de Direito Penal. Lisboa: Vega, 1998.

SALVADOR NETTO, Alamiro Velludo. Finalidades da pena: Conceito material de delito e sistema penal integral. São Paulo: Quartier Latin, 2009.

SANTISTEBAN, José Antonio Rodríguez. Los delitos contra el patrimônio en el código penal militar. Madrid: Reus, 2017.

SANTOS, Juarez Cirino dos. Manual de Direito Penal: parte geral. 2. ed. Florianópolis: Conceito, 2012.

SARAIVA, Alexandre de Barros José Leal. Código Penal Militar - comentado artigo por artigo: parte geral. 3. ed. revista e atualizada. São Paulo: Método, 2014.

SCHECAIRA, Sergio Salomão; CORRÊAA JUNIOR, Alceu. Teoria da Pena: Finalidades, direito positivo, jurisprudência e outros estudos de ciência criminal. São Paulo: Editora Revista dos Tribunais, 2002.

SCHÜLLER, Andreas. Can the international criminal court prosecute military personnel of United Nations Peace Spport Operations? In: MAROTO, Manuel; SCHEUNEMANN, Daniel. El derecho penal entre la guerra y la paz. Cuenca: Ediciones de La Universidad de CastillaLa Mancha, 2009.

SILVA SANCHEZ, Jesus Maria. Aproximación al derecho penal contemporâneo. 2. ed. Buenos Aires: B de F, 2012.

. Introducción. In: SCHÜNEMANN, Bernd. El sistema moderno del derecho penal: cuestiones fundamentales. Buenos Aires: B de F, 2012.

Introducción: Dimensiones de la sistematicidade de la teoria del delito. In. WOLTER, Jürgen; FREUND, Georg (eds.). El sistema integral del derecho penal: Delito, 
determinación de la pena y proceso penal. Trad. Guillermo Benlloch Petit, Nuria Pastor Muñoz, Ramon Ragués I Vallés, Ricardo Robles Planas, Pablo Sánchez-Ostiz Gutiérrez, Jesús-María Silva Sánchez. Madrid: Marcial Pons, 2004.

. Asesinatos selectivos en la 'guerra punitiva' contra el terrorismo. In Dret - Revista para el análisis del Derecho, Barcelona, 2017. Disponível em http://www.raco.cat/index.php/InDret/article/view/318315 . Acesso em 10 de janeiro de 2018.

La expanción del derecho penal: aspectos de la política criminal en las sociedades postindustriales. 2 ed. Buenos Aires: B de F, 2006.

Prólogo. In ROBLES PLANAS, Ricardo. La responsabilidad en los "delitos especiales": el debate doctrinal en la actualidad. Madrid: B de F, 2014.

SILVA, José Afonso da. Curso de Direito Constitucional positivo. 15. ed. São Paulo: Malheiros, 1998.

Notícia sobre a jurisdição militar no Brasil. In: ROCHA, Maria Elizabeth Guimarães Teixeira; PETERSEN, Zilah Maria Callado Fadul. Bicentenário da Justiça Militar no Brasil: Coletânea de Estudos Jurídicos. Brasília: Superior Tribunal Militar, 2008.

SILVA, Ovídio A. Baptista da Silva. Processo e Ideologia: o paradigma racionalista. 2. ed. Rio de Janeiro: Forense, 2006.

SILVEIRA, Renato de Mello Jorge. Crimes sexuais: bases críticas para a reforma do direito penal sexual. São Paulo: Quartier Latin, 2008.

Direito Penal Supra-individual: interesses difusos. São Paulo: Editora Revista dos Tribunais, 2003.

SIMPSON, Gerry. Law, War \& Crime. Malden. Polity Press, p. 159, 2007.

SOARES, Mário Sérgio Marques. O arrependimento posterior no código penal militar. Revista do Ministério Público Militar, no 13 (16): 29-35, p. 31, 1994.

SOARES, Mário Sérgio Marques; QUEIROZ, Péricles Aurélio Lima de. O Ministério Público Militar: o Período dos Generais (1964-1985). In: FREITAS, Ricardo et al. Memória Histórica do Ministério Público Militar. Brasília: Ministério Público Militar, 2012.

STREIFINGER, Marcello. O Tribunal do Júri na Justiça Militar do Estado. In: RAMOS, Dircêo Torrecillas; ROTH, Ronaldo João; COSTA, Ilton Garcia da (Coord.). Direito Militar: doutrina e aplicações. Rio de Janeiro: Elsevier, 2011. 
SWINARSKI, Christophe. Direito internacional humanitário como sistema de proteção internacional da pessoa humana. São Paulo: Revista dos Tribunais, 1990.

Introdução ao Direito Internacional Humanitário. Brasília: Comitê Internacional da Cruz Vermelha, 1997.

TAVARES, Juarez. Teoria do injusto penal. Belo Horizonte: Del Rey, 2003.

TEIXEIRA, Silvio Martins. Novo Código Penal Militar do Brasil. Rio de Janeiro: Freitas Bastos, 1946.

TELES, Fernando Hugo Miranda. Greve de militares, anistia e diálogos constitucionais. Revista do Ministério Publico Militar, Brasília - DF, n. 27, ano XLII, p. 203-230, nov. 2017.

VALENTE, Manuel Monteiro Guedes. Reflexões (breves) técnico-jurídicas sobre segurança interna. In. FERNANDES, Luís Fiães; VALENTE, Manuel Monteiro Guedes. Segurança Interna: reflexões e legislação. Coimbra: Almedina, 2005.

VERAS, Frederico Magno de Melo. Culpabilidade nos crimes propriamente militares. São Paulo: Leud, 2007.

VIEIRA DE ARAUJO, João. Direito Penal do Exército e da Armada. Rio de Janeiro: Laemmert \& C. editores, 1898.

VILLALBA PÉREZ, Francisca. Singularidades de los contratos del sector público en los âmbitos de la defensa y seguridade. In: OLARTE ENCABO, Sofía; ORZA LINARES, Ramón María. Estudios sobre derecho militar y defensa. Navarra: Aranzadi, SA, 2015.

WELZEL, Hanz. Derecho penal aleman: parte general. 11. ed., Trad. Juan Bustos Ramírez, Sergio Yãnez Pérez. Santiago do Chile: Juridica de Chile, 1997.

WIEACKER, Franz. História do Direito Privado Moderno. 3. ed. Tradução de A. M. Botelho Hespanha. Lisboa: Fundação Calouste Gulbenkian, 1967.

WOLTER, Jürgen; FREUND, George. Estudio sobre la dogmática y la ordenación de las causas materiales de exclusión del sobreseimiento del processo, de la renuncia a la pena y de la atenuación de la misma estrucuturas de un sistema integral que abarque el delito, el processo penal y la determinacion de la pena. In (eds). El sistema integral del derecho penal: Delito, determinación de la pena y proceso penal. Trad. Guillermo Benlloch Petit, Nuria Pastor Muñoz, Ramon Ragués I Vallés, Ricardo Robles Planas, Pablo Sánchez-Ostiz Gutiérrez, Jesús-María Silva Sánchez. Madrid: Marcial Pons, 2004. 
Petit, Nuria Pastor Muñoz, Ramon Ragués I Vallés, Ricardo Robles Planas, Pablo SánchezOstiz Gutiérrez, Jesús-María Silva Sánchez. Madrid: Marcial Pons, 2004.

ZAFEIROPOULOS, Dimitrios. Military Criminal Jurisdiction in Greece. Anais do X seminário de Direito Militar, Brasília, STM, 2014.

ZAPATERO, Luís Arroyo. La armonización internacional del derecho penal. In: MARTÍN, Adán Nieto. Piratas, mercenários, soldados, jueces y policias: nuevos desafios del derecho penal europeo e internacional. Cuenca: Ediciones de la Universidad de Castilla-La Mancha, 2010. 